\title{
Abordarea serviciilor ecosistemice în certificarea forestieră FSC: studiu de caz pentru pădurile cu valoare ridicată de con- servare din ocoale silvice de regim
}

\author{
R.E. Scriban, L. Nichiforel
}

Scriban R.E., Nichiforel L. 2021. Ecosystem services approach in the FSC forest certification process: a case study for high conservation values forests identified in private forest districts. Bucov. For. 21(1): 33-56

Abstract. The article presents an analysis of the role played by the forest certification process in the identification and the management of forest ecosystem services provided by High Conservation Value Forests (HCVFs). Data were collected from thirteen publicly available HCVFs reports which cover a total area of 117,507 ha. The process of HCVFs identification resulted in mapping 28,882 ha of forests providing high conservation values. The qualitative content analysis of the reports focused on the data sources used in the process of HCVFs identification: (i) forest management plans; (ii) management plans of the protected areas; (iii) other databases; (iv) stakeholder consultations and (iv) staff involvement. The results of the analysis showed that $80 \%$ of the area identified with HCVFs is the result of the integration of information from forest management plans. This is mainly the case for regulating forest ecosystem services (water protection, soil erosion, and air quality) and for forests located in strictly protected areas. The process of HCVFs identification also helps in the harmonization process between Natura 2000 management plans and forest management plans, especially by mapping the presence of rare and endangered species and habitats. One important added value of the HCVFs process is the identification of cultural ecosystem services by using the stakeholder consultation process and the involvement of technical staff. The additional services identified in the certification process can provide examples for the governmental design of payment schemes targeting forest owners providing ecosystem services beyond the legal limit imposed by the forest management plans. The analysis concludes that the forest management planning procedures provide a sound framework for addressing the forest ecosystem services, and that the certification process adds supplementary management measures as well as the requirement to monitor the provision of ecosystem services.

Keywords: forest certification, ecosystem services, management planning, high conservation value forests, stakeholder consultation

Author. Ramona-Elena Scriban (ramona.scriban@usm.ro), Liviu Nichiforel "Ștefan cel Mare" University of Suceava, Faculty of Forestry, 13 Universității, 720229 Suceava, Romania.

Manuscript received May 22, 2021; revised May 27, 2021; accepted May 29, 2021; online first May 30, 2021. 


\section{Introducere}

Serviciile ecosistemice (SE) sunt beneficiile materiale și imateriale pe care oamenii le obțin de la natură. Pădurile sunt ecosisteme complexe care oferă societății o gamă largă de beneficii ca de exemplu lemn, produse nelemnoase, fluxuri sigure de apă curată, sol productiv, protecție antierozională, sechestrare de carbon, servicii de recreere, biodiversitate etc.

Prima clasificare internațională comună a SE a fost realizată în Evaluarea Ecosistemelor Mileniului (Millennium Ecosystem Assessment 2005), unde SE sunt grupate în patru mari categorii: servicii de furnizare, care se referă la bunurile materiale, cum ar fi cheresteaua și produsele forestiere nelemnoase; servicii de reglare, cum ar fi controlul climatului, al calității apelor și a solului; servicii culturale, cum ar fi beneficiile spirituale și recreative și servicii suport, cum ar fi cele de habitat, ciclurile de nutrienți sau procesele de formare a solului (TEEB 2010).

SE sunt cunoscute în practica amenajării pădurilor din România drept funcții ale pădurilor (Drăgoi și Cîrnu 2016). Acestea sunt aplicate în țara noastră încă din 1954, prin zonarea funcțională propusă de profesorul dr. ing. Gh. Popescu-Zeletin și legiferată sub forma criteriilor pentru zonarea și gospodărirea funcțională a pădurilor (Anonymus 1954). Principiul de bază al acestui sistem de zonare funcțională este acela de a diferenția, în raport de criterii staționale, ecologice și sociale, pădurile care exercită primordial funcții speciale de protecție (grupa I), de cele care exercită primordial funcții de producție (grupa a II a). În cei 60 de ani de la introducerea zonării funcționale, încadrarea pădurilor României în grupa celor cu funcții prioritate de protecție a evoluat de la $14 \%$ în 1955, la 34\% în 1985 și la 53\% în 2015 (Popa și Pache 2016). Atribuirea, la nivelul fiecărui arboret, a uneia sau mai multor funcții este componenta cea mai importantă a deciziilor amenajistice, ce se concretizează în decizii tehnice privind stabilirea măsurilor silvotehnice posibil a fi executate, a intensității și periodicității in- tervențiilor, a lungimii perioadei de regenerare sau a structurii compoziționale a arboretului (Drăgoi 2004).

Analizând comparativ sistemul de clasificare internațional al SE cu zonarea funcțională națională, Nichiforel et al. (2021) identifică faptul că 10 din cele 14 categorii de SE sunt acoperite de categoriile funcționale existente în norma tehnică românească de amenajare (Anonymus 2018). Astfel, prin amenajamentele silvice pot fi fixate țeluri de producție pentru furnizarea de sortimente lemnoase sau țeluri de protecție identificate în servicii de reglare a apelor, solului și a climei, în servicii de recreere, sociale și de conservare a biodiversității. Singurele categorii din clasificarea internațională care nu sunt adresate în mod specific ca țeluri de gospodărire a pădurilor din România sunt cele de furnizare a produselor forestiere ne-lemnoase, serviciile de stocare a carbonului, valorile spirituale și religioase furnizate de ecosisteme și valorile estetice la nivel de peisaj (Nichiforel et al. 2021).

Odată cu demararea, în 2002, a procesului de certificare a ocoalelor silvice din România, zonarea funcțională a pădurilor a putut fi analizată și în raport de cerinţele standardelor internaţionale de certificare. Două scheme de certificare forestieră recunoscute la nivel internațional sunt prezente în România: FSCTM - Consiliul de Supraveghere a Pădurilor (Forest Stewardship Council) și PEFC ${ }^{\text {TM }}$ - Programul pentru avizarea certificării forestiere (Programme for the Endorsement of Forest Certification). La începutul anului 2021, peste 2,7 milioane de hectare de păduri, reprezentând aproximativ $40 \%$ din suprafața fondului forestier naţional, erau certificate conform standardului internațional de certificare FSC (FSC 2021), în timp ce primele suprafețe de pădure certificate PEFC au apărut la finalul anului 2020 (PEFC 2021).

Certificarea pădurilor are ca scop primordial standardizarea comună a unor principii de gestionare durabilă recunoscute la nivel internațional. Certificarea este un proces prin care se confirmă faptul că o anumită suprafață forestieră este gospodărită în conformitate cu cerințele 
standardului, în urma unui audit efectuat de o instituţie independentă, denumită organism de certificare.

Din perspectiva managerilor ocoalelor silvice de regim certificate, adoptarea acestui sistem voluntar de certificare s-a făcut în special pentru a obține avantaje economice (Hălilișan et al. 2018). Managerii chestionați consideră că sistemul aduce cerințe importante pentru îmbunătățirea managementului forestier, în special în ceea ce privește consultările publice, transparența, monitorizarea unor indicatori socio-economici și în conservarea biodiversității. Studiul concluzionează că adoptarea voluntară a standardului de către administrațiile silvice private arată interesul silvicultorilor de a se adapta la cerințele de piață și de a-și clarifica poziția în societate (Hălălișan et al. 2018).

Analizând legătura dintre prevederile legislative și cerințele standardului de certificare FSC se constată că majoritatea cerințelor standardului internaţional sunt acoperite de legislația naţională (Buliga și Nichiforel 2019). Studiul confirmă ipoteza că sistemul românesc de gestionare a pădurilor impune legislativ mare parte din cerințele de certificare. Din această perspectivă, respectarea cerințelor de certificare ar trebui să fie mai ușoară comparativ cu alte țări în care legislația silvică este mult mai permisivă (Nichiforel și Hujala, 2019). De exemplu, există țări europene în care procesul de amenajare a pădurilor nu este o cerință legală ci este cerută specific doar de standardele de certificare (Nichiforel et al. 2020).

Pe de altă parte, punerea în practică a cerințelor de certificare arată principalele provocări pe care le întâmpină administrația silvică în implementarea unui management forestier responsabil. Analizând abaterile identificate de auditori față de cerințele standardului pentru cele 108 rapoarte publice de audit din perioada 2008-2017 aflate în baza FSC, se constată că $54 \%$ din nereguli sunt în fapt abateri de la cerințele legislative și nu de la cerințele suplimentare ale standardului (Buliga și Nichiforel 2019). Aceiași analiză arată că peste $75 \%$ din non-conformitățile față de cerințele standardu- lui sunt legate de probleme sociale (cu referire de exemplu la siguranța în muncă, evaluarea impactului social, transparența și comunicarea publică) şi de mediu (cu referire la păduri cu valoare ridicată de conservare, specii rare și pe cale de dispariție, habitate ripariene și marginale, păstrarea de lemn mort și de arbori de biodiversitate).

O prevedere importantă a standardului FSC, suplimentar față de legislația națională o constituie identificarea, cartarea şi managementul pădurilor cu valoare ridicată de conservare (PVRC). Valorile ridicate de conservare (VRC) sunt definite de FSC în varianta lor generică (Jennings et al. 2003) şi presupun identificarea acelor păduri care au o valoare excepțională sau un rol critic din punct de vedere ecologic, social și cultural (Vlad et al. 2013). De aceea, conceptul de PVRC adresează cu precădere identificarea acelor păduri care furnizează în mod evident SE de suport, de reglare și culturale.

Ioraș et al. (2009) arătă că prin aplicarea conceptului de PVRC în România s-au adăugat prevederilor legale, cerințe voluntare de conservare a unor păduri cu rol cultural, istoric și religios respectiv de evaluare a importanței pădurilor pentru asigurarea nevoilor de bază a comunităților locale. Comparativ cu situația identificată în acea perioadă, suprafața pădurilor certificate în România a crescut semnificativ, iar sursele de date disponibile pentru identificarea PVRC s-au diversificat (Nichiforel et al. 2021).

Studiul de față își propune analiza modului în care certificarea forestieră, prin procesul de desemnare a PVRC, contribuie la identificarea unor SE adiționale comparativ cu funcțiile atribuite pădurilor prin amenajamentele silvice în vigoare. Mai precis, se urmărește analiza metodologiei de identificare a VRC, evidențiind sursele de date suplimentare față de cele prezentate de amenajamentele silvice. Un obiectiv subsidiar urmărește evidențierea măsurilor suplimentare de gospodărire și monitorizare impuse de standardul de certificare pentru SE identificate prin procesul PVRC. 
Tahel1 Clasificarea pădurilor cu valorilor ridicate de conservare și corespondența cu serviciile ecosistemice* Classification of High Conservation Value Forests and correspondence with ecosystem services*

\begin{tabular}{|c|c|c|c|}
\hline Categorie & Descriere & Sub-categorie PVRC & $\begin{array}{l}\text { Corespondenta cu clasificarea } \\
\text { serviciilor ecosistemice }\end{array}$ \\
\hline \multirow[t]{3}{*}{ PVRC 1.} & \multirow[t]{3}{*}{$\begin{array}{l}\text { Concentratiii de biodiversi- } \\
\text { tate semnificative la nivel } \\
\text { global, regional sau național. }\end{array}$} & PVRC 1.1 Arii protejate & $\begin{array}{l}\text { Menținerea habitatelor } \\
\text { reprezentative si a diversității } \\
\text { genetice }\end{array}$ \\
\hline & & $\begin{array}{l}\text { PVRC } 1.2 \text { Specii rare, amenințate, peri- } \\
\text { clitate și endemice }\end{array}$ & \multirow[t]{2}{*}{ Menținerea habitatului specii } \\
\hline & & PVRC 1.3 Utilizarea sezonală critică & \\
\hline PVRC 2. & $\begin{array}{l}\text { Peisaje forestiere extinse, } \\
\text { semnificative la nivel global, } \\
\text { regional sau național, în care } \\
\text { există populații viabile spe- } \\
\text { ciilor autohtone, în forma lor } \\
\text { naturală din punct de vedere } \\
\text { al distribuției și densității }\end{array}$ & & $\begin{array}{l}\text { Valori estetice la nivel de } \\
\text { peisaj }\end{array}$ \\
\hline \multirow[t]{4}{*}{ PVRC 3} & \multirow[t]{4}{*}{$\begin{array}{l}\text { Păduri ce cuprind ecosis- } \\
\text { teme rare, amenințate sau } \\
\text { periclitate }\end{array}$} & $\begin{array}{l}\text { 3a. Păduri, rariști de arbori, tufărișuri și } \\
\text { complexe de vegetație lemnoasă cu alte } \\
\text { tipuri de vegetație }\end{array}$ & \multirow[t]{4}{*}{$\begin{array}{l}\text { Mentinerea habitatelor } \\
\text { reprezentative si a diversității } \\
\text { genetice }\end{array}$} \\
\hline & & $\begin{array}{l}\text { 3b. Păduri și tufărișuri rare, relictare, } \\
\text { amenințate sau periclitate }\end{array}$ & \\
\hline & & $\begin{array}{l}\text { 3c. Ecosisteme forestiere naturale cu o } \\
\text { mare complexitate compozițională și } \\
\text { structurală }\end{array}$ & \\
\hline & & $\begin{array}{l}\text { 3d. Ecosisteme forestiere cu caracter } \\
\text { primar }\end{array}$ & \\
\hline \multirow[t]{3}{*}{ PVRC 4} & \multirow[t]{3}{*}{$\begin{array}{l}\text { Păduri care asigură servicii } \\
\text { de mediu esențiale în situații } \\
\text { critice }\end{array}$} & $\begin{array}{l}\text { PVRC 4.1. Păduri de importanță deose- } \\
\text { bită pentru sursele de apă. }\end{array}$ & $\begin{array}{l}\text { Calitatea apei şi protecția } \\
\text { surselor de apă }\end{array}$ \\
\hline & & $\begin{array}{l}\text { PVRC } 4.2 \text {. Păduri critice pentru } \\
\text { prevenirea și combaterea procesului de } \\
\text { eroziune. }\end{array}$ & $\begin{array}{l}\text { Protecția solului și prevenirea } \\
\text { eroziunii }\end{array}$ \\
\hline & & $\begin{array}{l}\text { PVRC 4.3. Păduri cu impact critic } \\
\text { asupra terenurilor agricole și calității } \\
\text { aerului. }\end{array}$ & Reglare climatică \\
\hline \multirow[t]{3}{*}{ PVRC 5} & \multirow{3}{*}{$\begin{array}{l}\text { Păduri esențiale pentru } \\
\text { satisfacerea necesităților de } \\
\text { bază ale comunităților locale }\end{array}$} & $\begin{array}{l}\text { 5a. Energie pentru încălzirea locuințelor } \\
\text { şi gătit }\end{array}$ & \multirow[t]{3}{*}{ Aprovizionare cu lemn } \\
\hline & & $\begin{array}{l}\text { 5b. Materiale de construcție a caselor și } \\
\text { dependințelor }\end{array}$ & \\
\hline & & $\begin{array}{l}\text { 5c. Materie primă pentru obținerea de } \\
\text { produse ce asigură veniturile necesare } \\
\text { subzistenței }\end{array}$ & \\
\hline \multirow[t]{4}{*}{ PVRC 6} & \multirow[t]{4}{*}{$\begin{array}{l}\text { Păduri esentiale pentru } \\
\text { păstrarea identității culturale } \\
\text { a unei comunități sau a unei } \\
\text { zone }\end{array}$} & $\begin{array}{l}\text { 6a. Păduri de care se leagă obiceiuri și } \\
\text { săbători locale ce se desfășoară tradițio- } \\
\text { nal în spațiul pădurii }\end{array}$ & \multirow[t]{2}{*}{ Valori spirituale și religioase } \\
\hline & & $\begin{array}{l}\text { 6b. Păduri simbol evocate în opere litera- } \\
\text { re sau legende }\end{array}$ & \\
\hline & & $\begin{array}{l}\text { 6c. păduri din vecinătatea unor monu- } \\
\text { mente istorice sau comunități religioase } \\
\text { declarate moumente istorice și/sau } \\
\text { culturale }\end{array}$ & \multirow[t]{2}{*}{$\begin{array}{l}\text { Valori culturale şi de patri- } \\
\text { moniu }\end{array}$} \\
\hline & & $\begin{array}{l}\text { 6d. Păduri ce fac parte din peisaje cu } \\
\text { valori ecologice, spirituale recunoscute } \\
\text { ca fiind semnificative la nivel regional } \\
\text { sau național. }\end{array}$ & \\
\hline
\end{tabular}




\section{Procesul de identificare PVRC}

Pentru România, procesul de identificare PVRC, ca parte din certificarea forestieră, a fost facilitat de realizarea unui ghid apărut inițial în 2005 (Stanciu et al. 2005) și revizuit în 2013 (Vlad et al. 2013). Odată cu apariţia în 2019 a standardului național de certificare FSC pentru România (FSC 2019) prevederile ghidului au devenit parte integrată a standardului. Cerințele standardului presupun identificarea și cartarea pădurilor care păstrează VRC, recomandarea unor măsuri de management pentru conservarea acestor valori și monitorizarea anuală a gradului de exercitare a valorilor de conservare.

Conform Principiului 9 din standardul de certificare și ghidului generic internațional (Jennings et al. 2003) pentru identificarea PVRC, atributele luate în considerare (i.e. VRC) sunt grupate în șase categorii (tabelul 1).

O cerință importantă de definire a suprafețelor pentru care există VRC este stabilirea pragului critic de la care să fie considerată valoarea excepțională sau rolul esențial pentru furnizarea SE stabilite prin cele șase categorii de PVRC. Aceste praguri se referă la caracteristici măsurabile (pantă, suprafețe minime etc.) sau la indicatori calitativi (stare de conservare nefavorabilă, impact socio-cultural major etc).

Planificarea procesului de identificare PVRC începe cu o evaluare preliminară care foloseşte în general sursele de date disponibile, în special amenajamente silvice și alte baze de date existente (planuri de management Natura 2000, baze cartografice ale ecosistemelor rare, etc). Evaluarea completă PVRC urmărește să stabilească și să verifice cu personalul de teren, specialiști și factori interesați existența valorilor de conservare și a valorilor critice definite prin ghidul de identificare (Vlad et al. 2013). Implicare personalului tehnic și consultările publice sunt importante atât în procesul de validare a suprafețelor cu VRC, cât și în stabilirea măsurilor de management și a indicatori- lor de monitorizare. Necesitatea de a stabili și aplica un proces de monitorizare a gradului de exercitare a funcțiilor furnizate de PVRC este o valoare adițională importantă a procesului de certificare comparativ cu situația amenajistică (Nichiforel et al. 2021).

\section{Metodologie}

Analiza metodelor practice de identificare a PVRC și a SE furnizate de acestea s-a realizat folosind informațiile publice existente pentru 13 ocoale silvice certificate sau aflate în proces de certificare (figura 1). Toate ocoalele silvice pentru care s-a realizat analiza sunt ocoale silvice de regim, administrând în mare parte păduri aparținând unităţilor administrativ teritoriale. Selecția acestora a fost condiţionată de existența informațiilor publice detaliate privind procesul de identificare PVRC.

Suprafața analizată este de 117.507 ha și include 93 de amenajamente (tabelul 2). Conform rapoartelor PVRC, au fost identificate VRC pe o suprafață netă de 21.962 ha, ceea ce reprezentă $18,7 \%$ din suprafața inclusă în certificare. Suprafața identificată cu VRC la nivel de ocol variază între 8\% și 37\%.

Suplimentar, rapoartele PVRC prezintă şi situaţia ariilor naturale protejate Natura 2000 din zona analizată. Rețeaua ecologică Natura 2000 are la bază două categorii: Arii Speciale de Conservare (SAC -Special Areas of Conservation) desemnate prin Directiva Habitate și recunoscute ca Situri de importanță comunitară (SCI) și Arii de Protecție Specială Avifaunistică (SPA - Special Protection Areas), desemnate conform Directivei Păsări. Pădurile analizate se suprapun pe 30.003 ha (26\% din suprafață) cu situri Natura 2000. Din cele 23 de arii naturale protejate, SCI respectiv SPA, 15 au planuri de management aprobate, două au plan de management, dar nu sunt aprobate, trei nu au planuri de management; din toate cele menționate doar 14 planuri au hărți de distribuție a speciilor. 


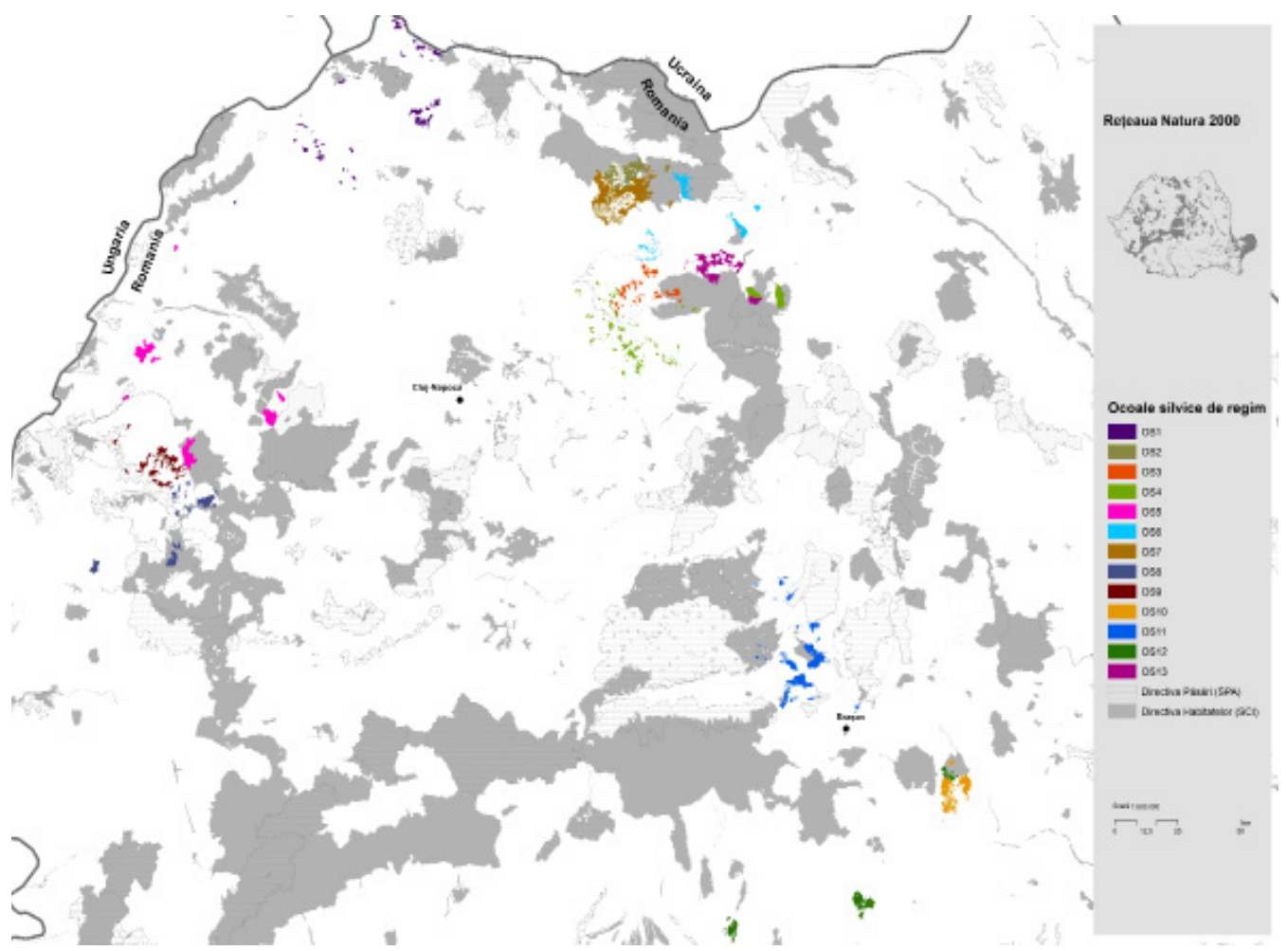

Figura 1 Localizarea ocoalelor silvice de regim integrate în analiza Spatial distribution of the private forests districts included in the analysis

Rapoartele PVRC au fost analizate atât din perspectivă cantitativă (pentru centralizarea suprafețelor identificate pe fiecare categorie VRC), cât și din perspectivă calitativă (identificarea surselor de date folosite). Analiza calitativă a surselor de date a clasificat informația folosită pentru identificarea PVRC în șase tipuri de surse de date: i) amenajamente silvice, ii) limite şi planuri de management ale ariilor naturale protejate, iii) baze de date privind ecosisteme primare, iv) alte baze de date geospațiale, v) informații primite de la personalul tehnic și vi) rezultate ale consultărilor publice (tabelul 3).

Analiza surselor de date s-a realizat prin crearea unei baze de date cu informațiile din cele 13 rapoarte publice PVRC, prin care, pentru fiecare categorie de PVRC s-au centralizat suprafețele incluse, defalcate în raport de sursele de date folosite pentru identificarea lor. În 38 acest fel se răspunde obiectivului de prezentare a PVRC care sunt comune cu amenajamentele silvice și a acelor suplimentar identificate prin apel la alte surse de date. Suplimentar, s-au preluat din rapoarte date privind măsurile de gospodărire și indicatorii de monitorizare stabiliți pentru fiecare categorie PVRC. Și pentru aceste situații analiza datelor diferențiază cerințele legale de management de cele asumate voluntar prin procesul de certificare.

În ceea ce privește informațiile privind consultările publice, acestea se regăsesc în rapoartele PVRC analizate, care prezintă lista factorilor notificați și a celor participanți. Pentru cele 13 ocoale silvice s-au trimis notificări către 668 de factori interesați reprezentând organizații din domeniul agențiilor guvernamentale (cu rol în protecția mediului, respectarea regimului silvic, a sistemului de gospodărire a apelor), administrații ale ariilor protejate, instituții 
Tabel 2 Suprafața de pădure analizată conform rapoartelor PVRC și suprapunerea cu ariile protejate Natura 2000 The forest areas analysed according to HCVFs reports linked to the Natura 2000 protected areas

\begin{tabular}{|c|c|c|c|c|c|c|c|c|c|}
\hline \multirow{3}{*}{$\begin{array}{l}\text { Nr. } \\
\text { crt. }\end{array}$} & \multirow{3}{*}{$\begin{array}{c}\text { Indicativ } \\
\text { ocol }\end{array}$} & \multirow{3}{*}{$\begin{array}{l}\text { Unități de } \\
\text { producție }\end{array}$} & \multicolumn{3}{|c|}{$\begin{array}{c}\text { Suprafața de pădure inclusă în } \\
\text { certificare }\end{array}$} & \multicolumn{4}{|c|}{ Natura 2000} \\
\hline & & & \multirow{2}{*}{$\begin{array}{c}\text { total } \\
\text { ha }\end{array}$} & \multicolumn{2}{|c|}{ din care PVRC } & \multirow{2}{*}{$\begin{array}{l}\text { Nr. de } \\
\text { SCI }\end{array}$} & \multirow{2}{*}{$\begin{array}{l}\text { Nr. de } \\
\text { SPA }\end{array}$} & \multirow{2}{*}{$\begin{array}{c}\text { Suprafataa } \\
\text { SCI+SPA } \\
\text { (ha) }\end{array}$} & \multirow{2}{*}{$\begin{array}{c}\% \text { din suprafața de } \\
\text { pădure }\end{array}$} \\
\hline & & & & ha & $\%$ & & & & \\
\hline 1 & OS1 & 26 & 9134 & 854 & 9,3 & 2 & 2 & 266 & 2,9 \\
\hline 2 & OS2 & 4 & 7594 & 1952 & 25,7 & 2 & 1 & 2293 & 30,2 \\
\hline 3 & OS3 & 2 & 5608 & 409 & 7,3 & 1 & & 1283 & 22,9 \\
\hline 4 & OS4 & 13 & 10935 & 2316 & 21,2 & 2 & 1 & 2728 & 25,0 \\
\hline 5 & OS5 & 4 & 11142 & 1083 & 9,7 & 2 & 1 & 4890 & 43,9 \\
\hline 6 & OS6 & 2 & 6467 & 2310 & 35,7 & 2 & 1 & 3768 & 58,3 \\
\hline 7 & OS7 & 4 & 17044 & 3779 & 22,2 & 1 & 1 & 3685 & 21,6 \\
\hline 8 & OS8 & 7 & 7280 & 551 & 7,6 & 3 & 1 & 3156 & 43,4 \\
\hline 9 & OS9 & 6 & 6757 & 655 & 9,7 & 1 & 1 & 358 & 5,3 \\
\hline 10 & OS10 & 6 & 7355 & 2695 & 36,6 & 2 & & 288 & 3,9 \\
\hline 11 & OS11 & 10 & 12764 & 2397 & 18,8 & 5 & 3 & 5160 & 40,4 \\
\hline 12 & OS12 & 6 & 7189 & 1428 & 19,9 & 1 & 0 & 449 & 6,2 \\
\hline \multirow[t]{2}{*}{13} & OS13 & 3 & 8239 & 1533 & 18,6 & 1 & 1 & 1681 & 20,4 \\
\hline & Total & 93 & 117.507 & 21.962 & & 25 & 13 & 30.003 & \\
\hline
\end{tabular}

Tahel 3 Clasificarea surselor de date descrise în rapoartele PVRC Data sources classification from HCFVs reports

\begin{tabular}{|c|c|c|c|}
\hline Nr.crt & Surse de date folosite & Informații & Disponibilitatea datelor \\
\hline 1 & Amenajamente silvice & $\begin{array}{l}\text { amenajamente silvice clasice cu infor- } \\
\text { mații ale descrierilor parcelare; } \\
\text { amenajamente în format GIS; } \\
\text { hărți amenajistice clasice/ GIS; }\end{array}$ & ocoalele silvice \\
\hline \multirow[t]{3}{*}{2.} & \multirow{3}{*}{$\begin{array}{l}\text { Baze de date privind } \\
\text { ariile naturale pro- } \\
\text { tejate }\end{array}$} & $\begin{array}{l}\text { hărți ale rezervațiilor naturale în } \\
\text { format GIS }\end{array}$ & http://www.mmediu.ro/articol/date-gis/434 \\
\hline & & limite ale siturilor Natura 2000 & http://natura2000.eea.europa.eu/\# \\
\hline & & $\begin{array}{l}\text { planuri de management ale ariilor } \\
\text { naturale protejate }\end{array}$ & http://ananp.gov.ro/ \\
\hline \multirow[t]{2}{*}{3.} & $\begin{array}{l}\text { Baze de date privind } \\
\text { ecosisteme primare }\end{array}$ & $\begin{array}{l}\text { hărți (Arhiva 1, Arhiva 2) în format } \\
\text { shapefile din cadrul proiectului } \\
\text { PIN-MATRA (2005) }\end{array}$ & http://mmediu.ro/categorie/paduri/25 \\
\hline & & $\begin{array}{l}\text { ecosisteme cu structuri primare Gre- } \\
\text { enpeace }(2017)\end{array}$ & $\begin{array}{l}\text { https://www.greenpeace.org/romania/ } \\
\text { raport/1235/harta-padurilor-virgine-potenti- } \\
\text { ale-si-studiul-situatia-padurilor-virgine-din-ro- } \\
\text { mania/ }\end{array}$ \\
\hline \multirow[t]{3}{*}{4.} & Alte baze de date GIS & Repertoriul Arheologic Național & http://map.cimec.ro/Mapserver/ \\
\hline & & captări de apă destinate potabilizării & $\begin{array}{l}\text { https://inspire-geoportal.ec.europa.eu/results. } \\
\text { html? country=ro\&view=details\&theme=ps }\end{array}$ \\
\hline & & harta zonelor de risc la tăieri ilegale & $\begin{array}{l}\text { http://certificareforestiera.ro/pag/har- } \\
\text { ta_risc_cont.php }\end{array}$ \\
\hline 5. & $\begin{array}{l}\text { Informații de la perso- } \\
\text { nalul tehnic }\end{array}$ & Identificare/validare PVRC & $\begin{array}{l}\text { Conform descrierii informațiilor din rapoartele } \\
\text { PVRC }\end{array}$ \\
\hline 6. & $\begin{array}{l}\text { Rezultate ale consul- } \\
\text { tărilor publice }\end{array}$ & Identificare/validare PVRC & $\begin{array}{l}\text { Conform descrierii rezultatelor consultării din } \\
\text { rapoartele PVRC }\end{array}$ \\
\hline
\end{tabular}


de învățământ, asociații de vânătoare, reprezentanți ai unităților administrativ teritoriale, agenți economici din exploatări forestiere, organizații non-guvernamentale de protecția mediului. S-au înregistrat 104 participanți la consultările publice preliminare și 86 participanți la consultările publice finale. De asemenea, rapoartele de evaluare PVRC au fost trimise către 15 organizaţii de mediu reprezentative la nivel naţional.

\section{Rezultate}

\section{Categorii de VRC identificate}

Conform rapoartelor PVRC, pentru cele 13 ocoale silvice integrate în analiză s-au identificat toate categoriile și sub-categoriile PVRC cu excepția PVRC 2 (peisaje forestiere extinse, semnificative la nivel global, regional sau naţional) şi PVRC 5 (păduri esenţiale pentru satisfacerea necesităților de bază ale comunităților locale). În primul caz, argumentul formulat este dat de imposibilitatea îndeplinirii pragului critic cerut de minim 35.000 ha de păduri cât mai puțin afectate de activităţi umane recente. Informațiile necesar a fi evaluate pentru PVRC 2 sunt legate de planurile de management ale ariilor naturale protejate și de bazele de date cu păduri primare. Chiar dacă procedura de evaluare permite alăturarea mai multor unităţi silvice pentru îndeplinirea pragului de suprafață, niciuna din unităţile analizate nu s-a regăsit într-o asemenea zonă. În ceea ce privește PVRC 5, rapoartele au luat în considerare harta zonelor de risc la tăieri ilegale (MMAP 2015) și rezultatele consultărilor publice cu comunitățile locale. Chiar dacă în multe situații harta prezenta zone cu presiune ridicată asupra pădurii, argumentată în special de necesitatea de asigurare a lemnului de foc, nu s-au identificat situaţii de atingere a pragului critic, respectiv de identificare a unor comunități care nu au alte alternative pentru a obține respectivele produse (de exemplu comunităţile sunt izolate cel puțin în anumite perioade ale 40 anului). Ținând cont că o pondere importantă a suprafeței analizate este reprezentată de păduri publice ale primăriilor, argumentul prezentat în consultările publice face referire la faptul că satisfacerea cererii de lemn de foc este în general asigurată prin hotărâri ale consiliilor locale de direcționare a unei cote de masă lemnoasă către membrii comunității.

Categoriile de PVRC identificate ocupă o suprafaţă netă de 21.962 ha, dar considerând suprapunerea spaţială a unor categorii de PVRC suprafața totală este de 28.865 ha. Din această suprafaţă totală, principalele categorii sunt cele încadrate în PVRC 4.2. (păduri critice pentru prevenirea și combaterea procesului de eroziune) care ocupă $35 \%$ din suprafața PVRC; PVRC 1.1. (păduri incluse în rezervații naturale) care ocupă $22 \%$ din suprafaţă, respectiv PVRC 4.1. (păduri de importanță deosebită pentru sursele de apă) care ocupă 21\% din suprafețe (figura 2).

Luând în considerare corespondența dintre PVRC și categoriile de SE (tabelul 1), VRC identificate se reflectă cu prioritate în zona SE de reglare (PVRC 4) care ocupă 57\% şi a SE suport - habitat (PVRC 1 și PVRC 3) care ocupă 41\% din suprafață. Serviciile cu rol cultural reprezintă $3 \%$ din totalul PVRC.

\section{Procesul de identificare PVRC 1}

PVRC 1.1. Suprafețe forestiere din arii protejate. La nivelul acestei categorii de PVRC, pragul critic presupune identificarea tuturor suprafețelor de păduri care sunt integrate în rezervații științifice, rezervații naturale, suprafețe declarate monumente ale naturii și zone de protecție integrală sau zone de protecție strictă din ariile naturale, protejate conform Legii 49 /2011 și O.U.G. 57/2007. Conform cerințelor amenajistice, aceste suprafețe sunt excluse de la orice intervenție silviculturală. Pentru verificarea modului în care în suprafaţa certificată există rezervații științifice, care îndeplinesc criteriile PVRC 1.1 ghidul recomanda folosirea limitelor spațiale în format vectorizat. $\mathrm{Cu}$ toate acestea, trebuie luat în considerare fap- 


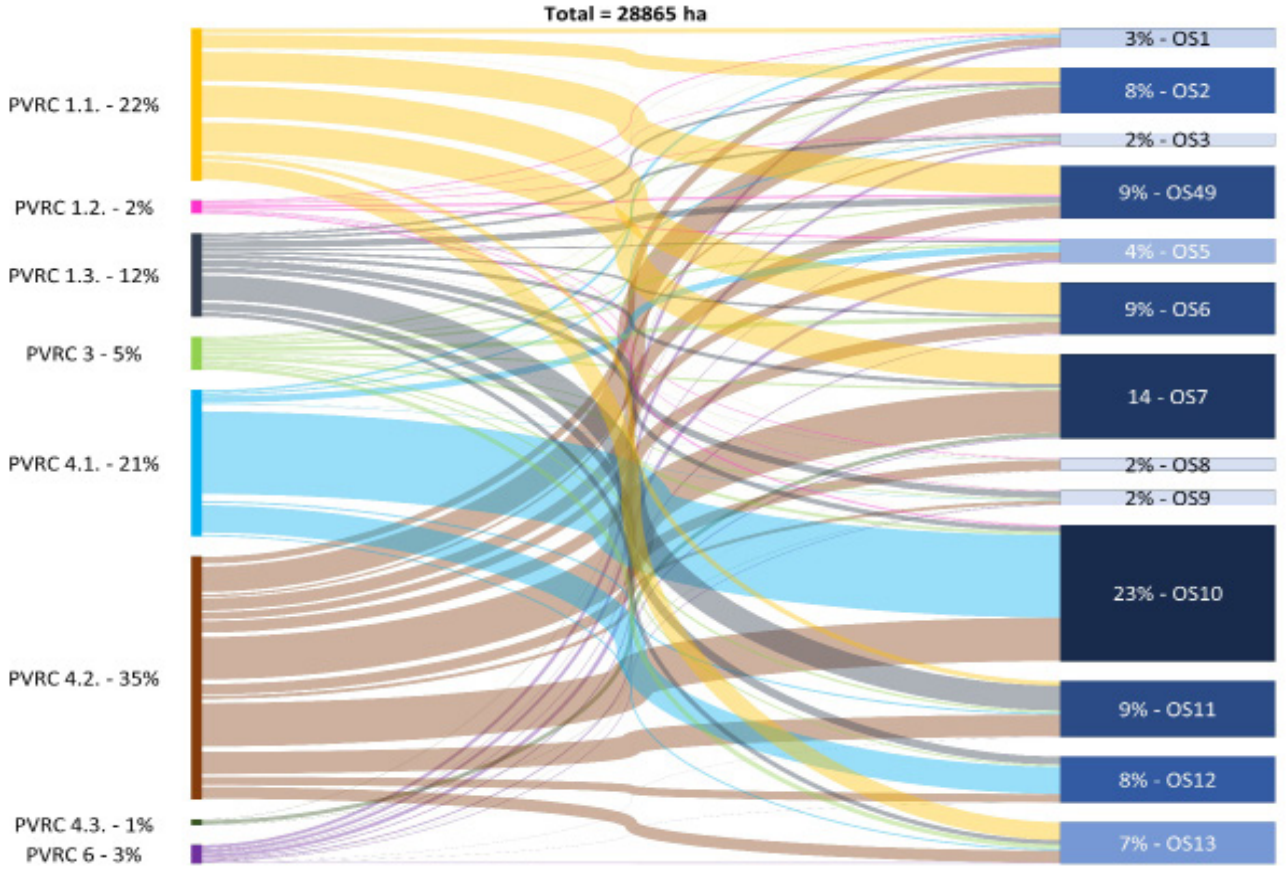

Figura 2 Categorii de PVRC identificate la nivelul fiecărui ocol silvic

High Conservation Value Forests categories identified at each forest districts

tul că limitele geospațiale disponibile public la nivel guvernamental pot fi și pentru rezervații aflate în diferite faze de aprobare sau de armonizare (ca de exemplu limitele propuse prin proiectul INSPIRE). În aceste situații este necesară integrarea în PVRC 1.1. doar a rezervaţiilor definite prin Legea 5/2000 privind aprobarea Planului de amenajare a teritoriului național - Secțiunea a III-a - zone protejate (Anonymous, 2000).

Conform rapoartelor analizate, toate suprafețele incluse în rezervații se regăseau încadrate corespunzător și în amenajamentele silvice. Un caz particular îl reprezintă Rezervația Naturală Pădurea Noroieni, cu o suprafață de 221,4 ha care nu apare distinct în Legea 5/2000, dar care face parte din aria naturală protejată ROSCI0214-Râul -Tur și ROSPA0068-Lunca interioara a Turului. În acest caz, sursa de informație folosită la identificare a fost planul de management al ariei naturale protejate, care prevede încadrarea rezervației în categoria funcțională 1.5.c și implicit în PVRC 1.1.

PVRC 1.2. Păduri care adăpostesc specii rare, amenințate, periclitate sau endemice. În PVRC 1.2 au fost încadrate acele păduri ce adăpostesc concentrații ridicate de specii de floră, importante pentru conservare. Conform datelor din rapoartele PVRC, sursele de identificare a speciilor de floră care să se încadreze în categoria PVRC 1.2. sunt diverse: (i) baza de date a rețelei ecologice Natura 2000, (ii) planurile de management aprobate ale ariilor naturale protejate, cu hărțile de distribuție aferente fiecărei specii, (iii) amenajamentele silvice, (iv) Anexa 1 din ghidul PVRC în funcție de habitatul specific florei și locația regională a pădurilor, (v) alte studii de biodiversitate, respectiv (vi) implicarea personalului silvic în identificarea și validarea prezenței speciilor. Pentru ocoalele silvice analizate doar 2\% (552 ha) sunt suprafețe care adăpostesc specii de floră rare, amenințate, periclitate sau ende- 

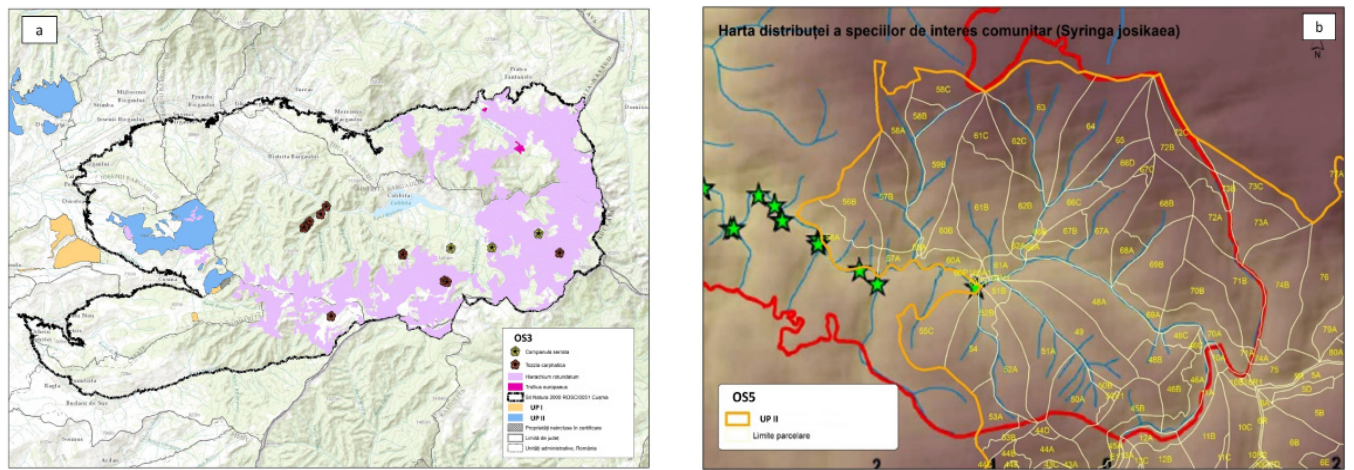

Figura 3 Exemplu de VRC 1.2. identificat cu ajutorul hărților de distribuție a) în format .shp şi b) georeferențiat Example of HCV 1.2. identified by using species map distribution a) with .shp file, and b) georeferenced map

mice.

Sursa principală de identificare pentru PVRC 1.2. este reprezentată de planurile de management ale ariilor naturale protejate. Conform rapoartelor există 26 de specii de floră care ocupă $60 \%$ din suprafețele aferente PVRC 1.2. Dintre acestea, 20 de specii se regăsesc în Rezervația Naturală 2.677 Dunele de nisip de la Foieni, integrată în Situl Natura 2000 ROSPA0016 Câmpia Nirului-Valea Ierului. Pentru șase specii (Hieracium rotundatum Kit. ex Schult., Syringa josikaea J. Jacq., Campanula serrata - (Kit.) Hendrych, Traunsteinera globosa (L) Rchb, Drepanocladus vernicosus - (Mitt.) Warnst. și Drosera rotundifolia L.) s-au folosit informațiile din hărțile de distribuție existente în trei planuri de management. Doar într-un singur caz (ROSCI0051 Cușma) s-au găsit date geospațiale disponibile publicului larg în format shp (figura 3a); în rest, pentru localizarea zonelor de interes, s-au folosit hărțile de distribuție din planurile de management, georeferenţiate și suprapuse peste hărțile amenajistice GIS (figura $3 b$ ).

Pentru a putea fi validate la subcategoria PVRC 1.2, s-a luat în considerare și starea de conservare a speciilor de interes comunitar conform informațiilor preluate din planurile de management ale ariilor naturale protejate. Starea de conservare reprezintă totalitatea factorilor abiotici sau biotici care pot influența distribuţia şi abundenţa populațiilor speciei respective. Pragul critic este îndeplinit prin rezultatele obținute din evaluarea parametrilor pentru starea de conservare a unei specii exprimată în patru categorii: favorabilă, nefavorabil-inadecvată, nefavorabil-rea și necunoscută. Astfel, în $68 \%$ din suprafețele stabilite ca PVRC 1.2. populația speciilor de floră are o stare de conservare nefavorabilă-inadecvată, fiind validate însă şi suprafețe în care starea de conservare era favorabilă, dacă speciile aveau o prezență sporadică.

De menționat că acolo unde prezența hărților de distribuţie a speciilor se suprapune peste rezervații naturale identificate ca PVRC 1.1. (păduri incluse în SUP E), suprafețele nu au mai fost evaluate și din perspectiva PVRC 1.2. Este cazul unor păduri din OS2, OS4, OS6 și OS7 care se suprapun cu zonele de strictă protecție a parcurilor naționale Munții Rodnei, respectiv Munții Călimani unde managementul și monitorizarea speciilor floristice rare este de competența administrației parcurilor și, de asemenea, pragul critic este deja stabilit prin încadrarea zonei în PVRC 1.1.

Un aspect important în stabilirea suprafețelor cu concentrație critică în diversitate florală este validarea acestor suprafețe de către personalul de teren al ocoalelor. Mai mult, $40 \%$ din suprafețele cu VRC 1.2 au fost identificate și validate doar cu ajutorul personalului de teren pentru trei specii de floră: Fritillaria meleagris 
L., Ruscus aculeatus L. și Paeonia officinalis

L. ssp. Banatica (Rochel) Soó.

PVRC 1.3. Păduri cu utilizare sezonală critică. Pădurile cu utilizare sezonală critică, fac referire la speciile de faună și sunt reprezentate atât de locurile critice pentru perioada de reproducere, pentru adăpost sau iernat, cât și cele pentru migrare. Suprafetele identificate ca PVRC 1.3 reprezintă $13 \%$ din totalul suprafețelor cu PVRC, ocupând 3451 ha.

Identificarea pădurilor critice pentru faună s-a realizat pe baza acelorași surse de date disponibile prezentate la PVRC 1.2. Suplimentar, identificarea unor zone critice poate fi evaluată și conform amenajamentului silvic pentru arboretele încadrate în categoria funcțională 1.5.i - Păduri destinate ocrotirii unor specii rare din fauna indigenă (cocoși de munte, capră neagră, urşi ş. a.) sau colonizată (mufloni, capră ibex etc.). Conform acestei categorii funcționale, s-a localizat prezența speciei Tetrao urogallus (cocoș de munte) identificată la nivelul a două ocoale silvice, OS6 și OS13, pe o suprafață de
96,49 ha.

Sursa principală de identificare a suprafețelor cu PVRC 1.3 este reprezentată de informațiile furnizate de planurile de management ale ariilor naturale protejate care contribuie la identificarea a $81 \%$ din suprafețele cu VRC 1.3. Etapele de lucru sunt similare cu cele menționate la PVRC 1.2. și presupun folosirea hărților de distribuție aferente fiecărei specii. Cele mai multe specii au fost identificate la nivelul Ariilor de Importanță Avifaunistică (figura 4), cu peste 30 de specii de păsări, pe o suprafață totală de pădure de 1940 de ha, din care aproximativ 900 de ha se regăsesc la nivelul OS11 și care se suprapune peste două arii protejate ROSPA0093 Pădurea Bogătii și ROSPA0027 Dealurile Homoroadelor.

Din categoria mamiferelor mari fac parte Ursus arctos (ursul brun), Canis lupus (lup) și Lynx lynx (râs), prezente la nivelul a șase ocoale silvice de regim (OS4, OS6, OS10, OS11, OS12 și OS13). Conform informațiilor oferite de hărțile de distribuție a speciilor se întâlnesc două situații în care acestea pot fi identificate,

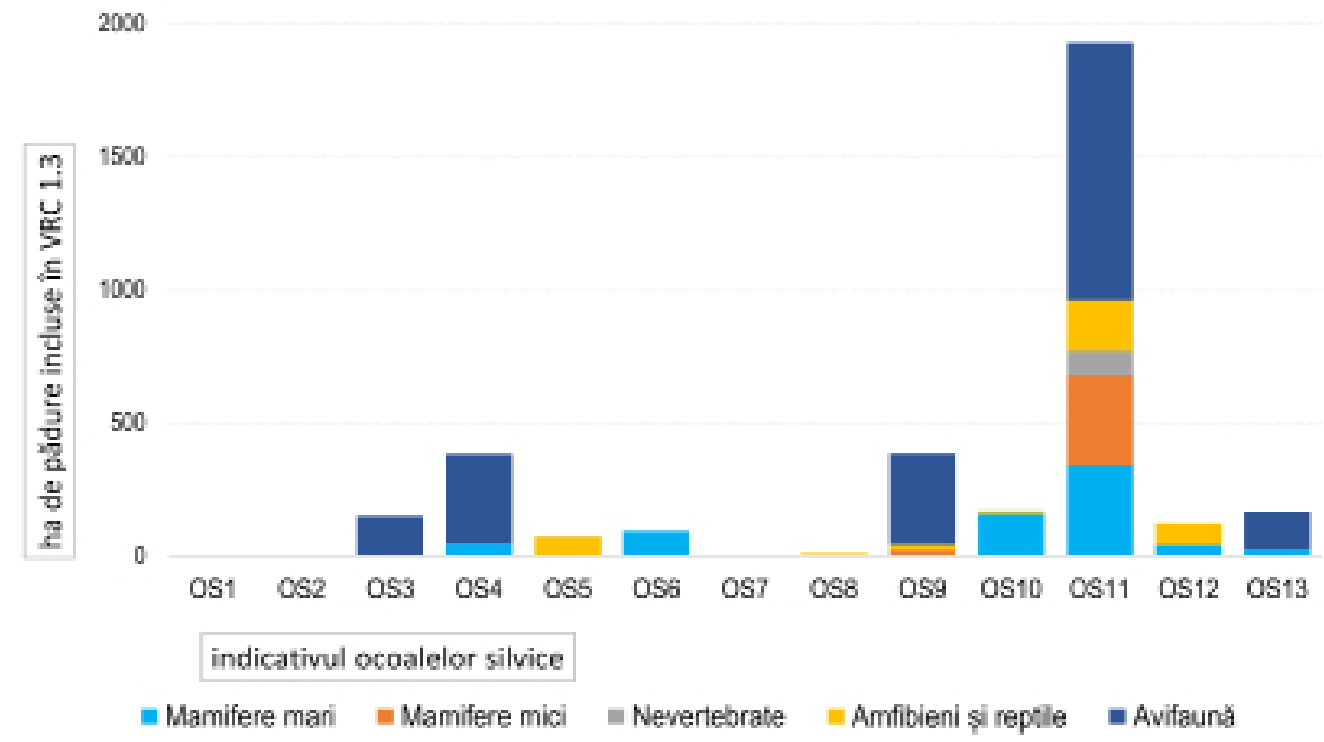

Figura 4 Repartiția pădurilor cu utilizare sezonală critică în funcție de categoriile de faună identificate Distribution of forests areas of critical seasonal use according to fauna categories 


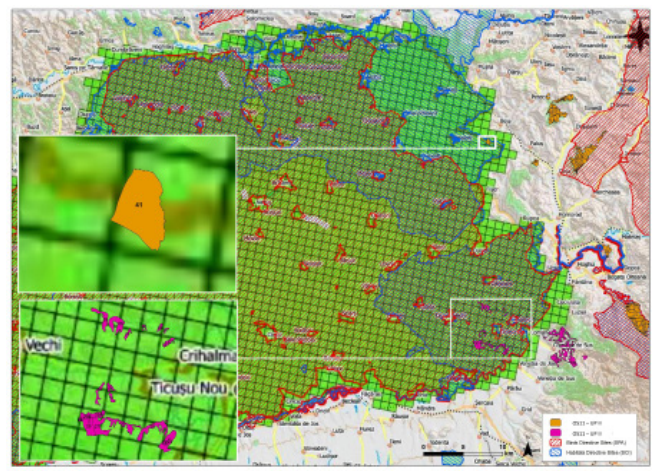

Figura 5 Exemplul unei hărți de distribuție a arealului pentru specia Ursus arctos raportat la întregul sit Natura 2000

Example of an area distribution map for Ursus arctos linked to the entire Natura 2000 site

fie la nivelul întregului areal de distribuție raportat la întregul sit sau tipului de habitat (figura 5), fie prin metoda inventarierii semnelor de prezență a speciei (figura 6). În nici un plan de management nu se menționează locația pentru bârloguri de urs sau vizuini de lup, respectiv râs. Deși specia C. lupus nu este menționată în anexa 2 a ghidului PVRC, aceasta a fost inclusă ca PVRC deoarece în România este considerată o specie protejată, prezentă în anexele II şi IV din Directiva Habitate și clasificată ca fiind o specie prioritară pentru conservare.

Implicarea personalului tehnic rămâne, de asemenea, o sursă importantă de identificare și validare a suprafețelor cu concentrații critice de faună. Datele analizate arată că 264 ha au fost identificate ca PVRC 1.3 ca urmare a implicării personalului tehnic, în special pentru locaţii specifice a bârlogului de urs și a locurilor de rotit cocoș de munte. Un caz particular se întâlnește în cadrul OS12, unde există un studiu independent de biodiversitate realizat de ocol; în urma evaluărilor de teren, 284,4 ha de pădure au fost desemnate voluntar ca zonă de conservare a biodiversității. Acest fapt constituie un model de conservare a unei zone reprezentative în care au fost identificate concentrații ridicate de biodiversitate pentru carnivorele mari, păsări și amfibieni: $U$. arctos, 44

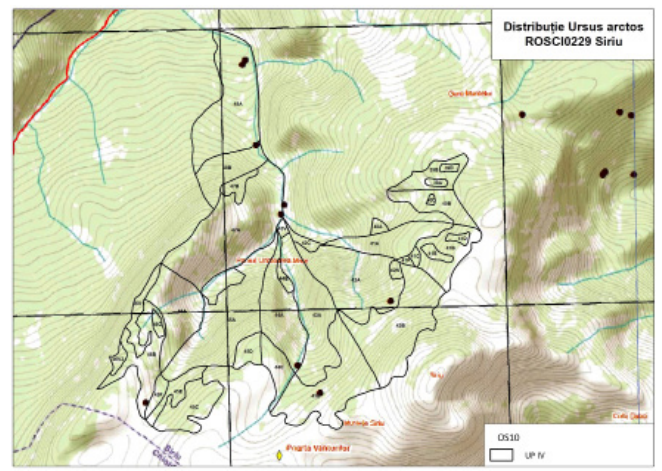

Figura 6 Exemplul unei hărți de distribuție a speciei de Ursus arctos folosind metoda inventarierii semnelor de prezență a speciei

Example of an area distribution map for Ursus arctos using the presence marks inventory method

C. lupus, L. lynx, Dryocopus martius, Dendrocopos leucotos, Ficedula albicollis, Ficedula parva și Bombina variegata.

\section{Procesul de identificare PVRC 3}

În această categorie de PVRC sunt incluse ecosistemele forestiere rare, ameninţate sau periclitate fie de activităţi antropice, fie de schimbarea condițiilor de mediu, dar și cele care se constituie în habitate cu o mare complexitate compoziţională și structurală. Pentru această categorie de PVRC au fost incluse 1380 ha de pădure, reprezentând 4,7\% din totalul PVRC și 1,2\% din suprafața de pădure inclusă în certificare. Sursele de date folosite pentru evaluarea acestor suprafețe de păduri fac referire la (i) tipul de pădure natural fundamental atribuit prin amenajamentul silvic, (ii) categoriile funcționale care descriu condiții de mediu limitative, (iii) proporția de participare a speciei principale în compoziție, (iv) planurile de management ale ariilor naturale protejate, inclusiv hărțile de distribuție a tipurilor de habitate, (v) informațiile disponibile ale pădurilor cu structură primară și (vi) consultările publice cu factorii interesați.

Amenajamentul silvic constituie o sursă utilă de informație, deoarece facilitează co- 
respondența între ecosistemele forestiere rare, amenințate și periclitate și tipurile de pădure identificate amenajistic (Anexa 4 din ghidul PVRC - Vlad et al, 2013). Conform datelor din cel 13 rapoarte, suprafața PVRC 3 identificată pe baza amenajamentelor silvice este de 762 ha, reprezentând $55 \%$ din totalul pădurilor incluse în VRC 3. Deși ghidul nu prevede identificarea ecosistemelor forestiere prin funcțiile de protecție atribuite pădurii, datele analizate arată că au fost luate în considerare în evaluare și pădurile încadrate în categoriile funcționale care descriu condiții limitative (1.2.c, 1.2.i şi 1.3.f). Acestea ocupă o pondere semnificativă de $32 \%$ din totalul suprafețelor ocupate de PVRC 3. Suplimentar, conform datelor din amenajamentele silvice au fost luate în considerare și acele unități amenajistice unde predomina în compoziția arboretului

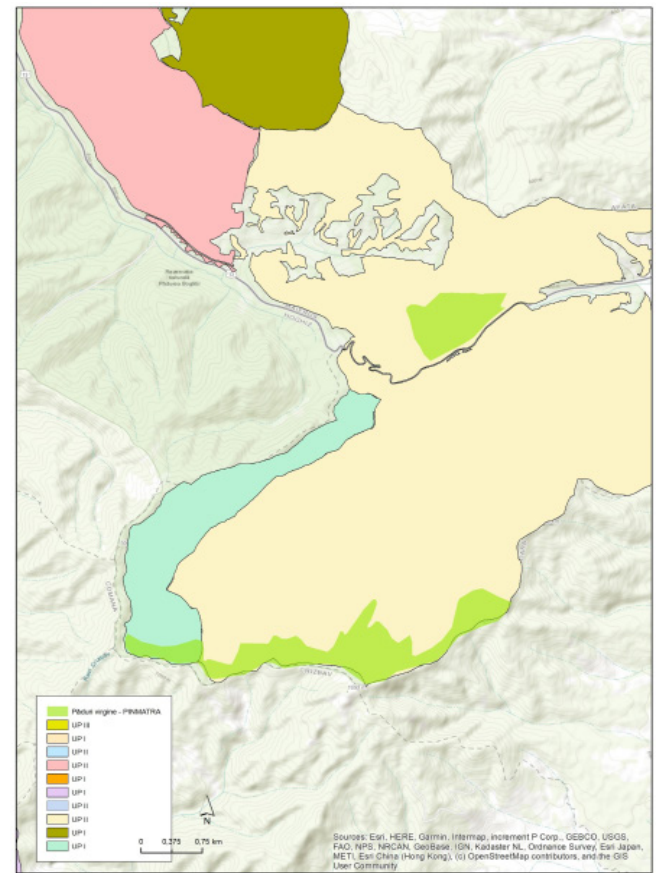

Figura 7 Exemplu de suprafețe de păduri cu structuri primare identificate folosind baza de date vectoriale PIN-MATRA cu suprapunerea pădurilor din OS11

Example of primary forests identified in OS11 using PIN-MATRA vector data base method una din speciile de Alnus sp., Pinus banksiana Lamb., Pinus ponderosa Laws. şi Fraxinus sp. Astfel, au fost identificate ecosisteme periclitate pe o suprafață totală de 125 ha, însemnând 9\% din PVRC 3.

În ceea ce privește prezența ecosistemelor forestiere în ariile naturale protejate, acestea pot fi localizate cu ajutorul hărților de distribuție din planurile de management. Conform datelor analizate, doar într-un singur caz a fost identificată prezența habitatului 91E0* - Păduri aluviale cu Alnus glutinosa (L) Gaertn. şi Fraxinus excelsior L., suplimentar datelor existente în amenajamentele silvice.

Adițional față de informațiile din amenajamente, au fost identificate cu ajutorul personalului de teren, ecosisteme considerate reprezentative datorită diversităţii compoziționale și/sau structurale. Astfel, au fost validate de

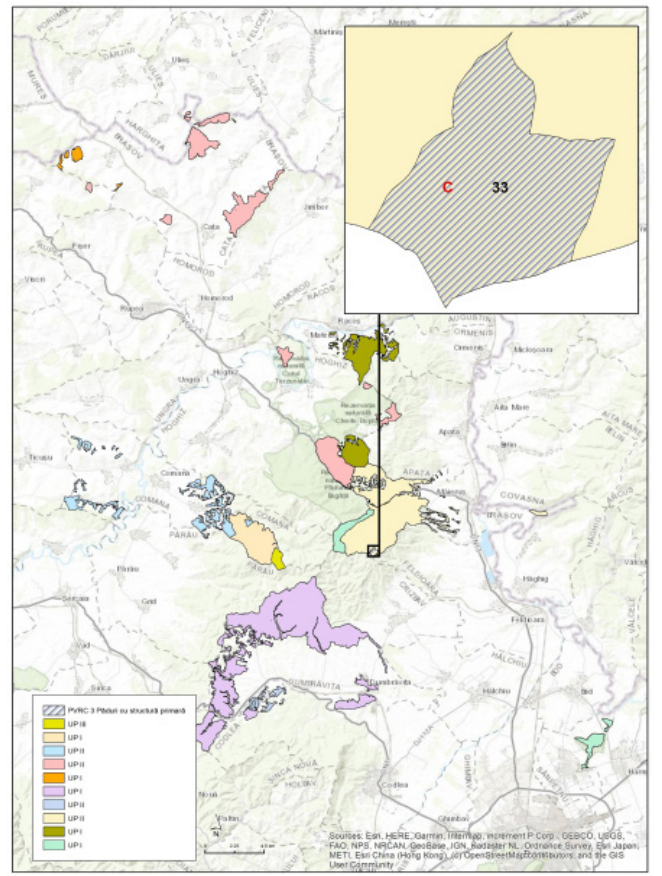

Figura 8 Exemplu de suprafețe de păduri cu structuri primare validate în urma evaluărilor în teren la nivelul OS11

Example of primary forest validated following field assessments in OS11 
reprezentantiii ocoalelor silvice un total de 141 ha, din care 59 ha sunt localizate într-o fostă bază experimentală de cercetări silvice (Rezervația Cucureasa), iar diferența este dată de ecosisteme periclitate de Alnus sp. sau F. excelsior.

La această categorie PVRC, o sursă esenţială necesar a fi evaluată din perspectiva utilității o reprezintă baza de date privind localizarea potențialelor păduri primare. Pentru identificarea lor s-au folosit hărțile vectoriale cartate în urma studiului PIN-MATRA (Biriș și Veen 2005), iar după 2017 și harta geospațială din studiul Greenpeace (Greenpeace 2017). Prin suprapunerea zonelor cartate a ecosistemelor cu structură primară cu pădurile certificate ale ocoalelor silvice private a rezultat o suprafață potențială de 1937 ha (figura 7). Înainte de a fi evaluate în teren, aceste arborete au fost trecute prin filtrul criteriilor și indicatorilor de selecție a ecosistemelor cu caracter primar, conform OM nr. 3397/2012, multe suprafețe neîndeplinind criteriul de vârstă și/sau de structură. Suprafețele care îndeplineau aceste condiții au fost validate cu personalul de teren (figura 10) și cumulează 472 ha de pădure cu structură primară, localizată în opt ocoale silvice. Suplimentar, în două din cele opt ocoale silvice, există păduri cu structuri primare incluse și în zona de protecție strictă a Parcului Național Munții Rodnei (PVRC 1.1.) și, drept urmare, aceste suprafețe nu au mai fost încadrate la PVRC 3 fiind oricum excluse de la orice intervenție silviculturală.

Pentru identificarea pădurilor cu structuri primare s-au utilizat și informațiile obținute din consultările publice. Astfel, ca urmare a consultării publice realizate la OS4, a fost primită o notificare din partea INCDS "Marin Drăcea" Câmpulung Moldovenesc privind existența unei suprafețe de pădure cu caracter primar. Suprafața de 45,4 ha a îndeplinit condițiile de pădure cvasivirgină fiind integrată la PVRC 3 şi întocmindu-se demersurile pentru încadrarea ei în Catalogul Naţional al Pădurilor Virgine.

\section{Procesul de identificare PVRC 4}

Aceste păduri asigură serviciile de mediu cu rol de reglare iar valorile de conservare aferente sunt foarte apropiate de funcțiile de protecție atribuite pădurii prin amenajamentele silvice. $\mathrm{Cu}$ toate acestea, încadrarea funcțională a unor păduri a fost reanalizată, atât cu ajutorul personalului tehnic de teren, cât și cu ajutorul bazelor de date și informațiilor preluate din consultările publice.

La nivelul celor 13 ocoale silvice, pădurile cu rol de reglare ocupă mai mult de jumătate din suprafața totală PVRC, cu un procentaj de 57\%, defalcat în 35\% PVRC 4.2 (păduri de importanță deosebită pentru sursele de apă), 21\% PVRC 4.1 (păduri critice pentru prevenirea și combaterea procesului de eroziune) și 1\% PVRC 4.3 (păduri cu impact critic asupra terenurilor agricole și calităţii aerului).

\section{PVRC 4.1. Păduri de importanță deosebită} pentru sursele de apă. Conform rapoartelor PVRC, aceste păduri ocupă o suprafață totală de aproximativ 5900 ha. Suprafețele se regăsesc în toate cele trei subcategorii respectiv (i) păduri care asigură protecția surselor de apă potabilă, (ii) păduri din jurul bazinelor hidrografice și (iii) păduri ripariene cu rol de protectie a malurilor cursurilor de apă.

Amenajamentul silvic este principala sursă de identificare PVRC 4.1 pentru pădurile care fac parte din categoriile functionale aferente sub-grupei 1.1 - arborete cu rol de protecție a apelor. Suprafața totală ocupată de aceste arborete este de 5700 ha, adică $93 \%$ din totalul PVRC 4.1. Majoritatea lor sunt localizate în OS7, OS10 și OS12, unde se regăsesc suprafețe însemnate de păduri aflate în perimetrul lacurilor de acumulare şi încadrate în categoria funcțională 1.1.g (figura 9).

O altă sursă de date o reprezintă consultările cu personalul de teren, respectiv cu factorii interesaţi și care au adus informații relevante pentru suprafețele unde sunt prezente captări de apă. Astfel, la nivelul a șase ocoale silvice s-au 


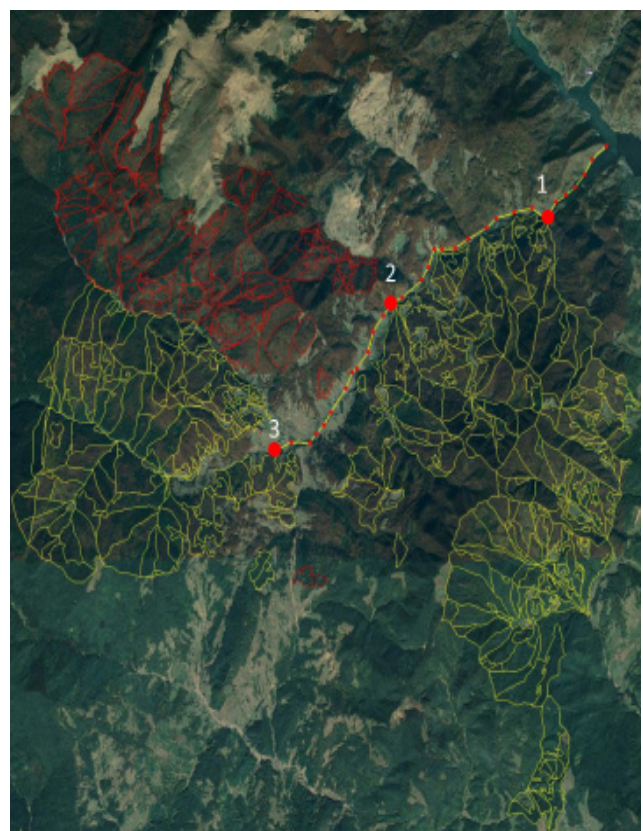

Figura 9 Exemplu de identificare a pragului critic pentru PVRC 4.1. prin identificarea distanței dintre pădure și lacul de acumulare

Example of identifying the critical importance for HCVF 4.1. by measuring the distance between forests and the water storage reservoir

desemnat 370 ha de pădure ca zone tampon pentru captările de apă. În rapoartele PVRC realizate după 2019, a fost luată în considerare și baza de date vectoriale a captărilor de apă potabilă, ceea ce a dus la localizarea unei captări de apă prezentă la nivelul OS11, cu o suprafață de protecție de 4,1 ha (figura 10).

VRC 4.2. Păduri critice pentru prevenirea și combaterea procesului de eroziune. Categoria PVRC 4.2. ocupă 10.083 ha având cea mai mare pondere din suprafața totală a PVRC. Pădurile aflate pe terenuri cu eroziune evidentă sau cu pante mari cuprinse, între 30$35 \mathrm{~g}$, reprezintă 89\% din PVRC 4.2, 6\% sunt păduri aflate pe terenuri înmlăștinate, terenuri mobile sau alunecătoare, iar $4 \%$ sunt suprafețe de pădure cu rol de prevenire a avalanșelor. Toate aceste suprafețe sunt identificate pe baza

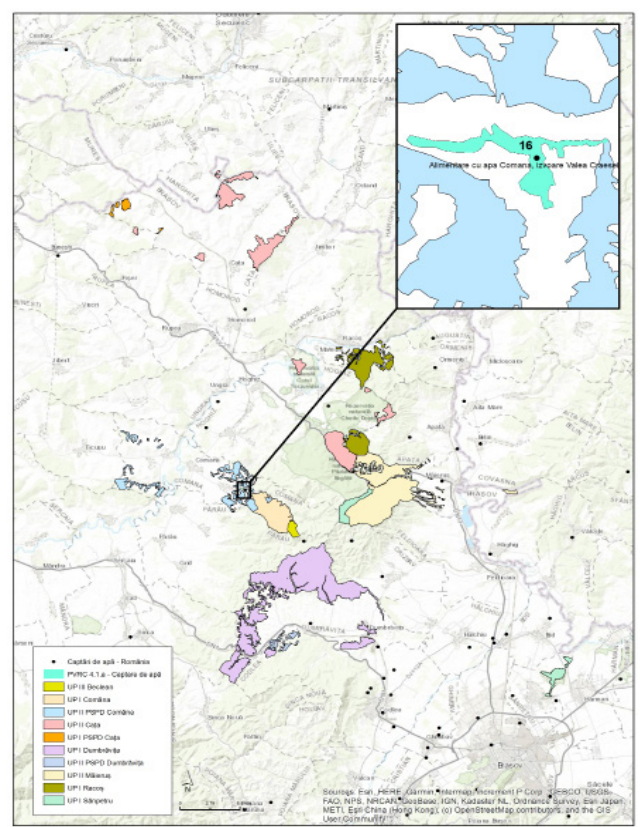

Figura 10 Exemplu de folosire a bazei de date vectoriale cu captări de apă pentru identificarea PVRC 4.1.a

Example of using vector database with water catchments to identify HCVF 4.1.a

categoriilor funcționale existente în amenajamentele silvice.

Suplimentar, personalul de teren a avut o contribuție importantă la excluderea sau includerea unor suprafețe care nu îndeplinesc criteriile de pantă sau eroziune. Astfel, la nivelul OS3, OS9 și OS11 au fost adăugate 84 ha de păduri care prezintă un grad ridicat de eroziune.

\section{PVRC 4.3. Păduri cu impact critic asupra} terenurilor agricole și calității aerului. Categoria PVRC 4.3 a fost identificată pe o suprafață de 231 ha, din care $85 \%$ sunt acoperite de categoriile funcționale atribuite prin amenajamentele silvice. În cazul ocoalelor OS1 și OS9 consultările publice au adus informații suplimentare pentru identificarea unor păduri limitrofe unor gropi de gunoi cu un rol important 
împotriva poluării solului, validate ca PVRC 4.3 pe 34 ha.

\section{Procesul de identificare VRC 6}

Această categorie de PVRC grupează SE cu rol cultural. Îndeplinirea pragului critic se referă la: (i) păduri unde există obiceiuri sau tradiţii cu importanță istorică, (ii) păduri menționate în literatura românească, unde valoarea pădurii este transmisă prin legende sau opere literare, (iii) păduri în vecinătatea unor lăcaşuri de cult sau monumente istorice sau (iv) păduri cu valoare peisagistică ridicată aflate în rezervații naturale sau alte monumentele ale naturii.

Conform rapoartelor PVRC, aceste păduri au fost identificate prin (i) categoriile funcționale atribuite prin amenajamentul silvic, (ii) baza cartografică a Repertoriul Arheologic Național, (iii) consultările publice atât cu personalul silvic cât și cu factorii interesați și (iv) alte surse de date cum ar fi, hărți turistice sau documentare în literatura românească. În urma evaluării, au fost identificate 780 ha păduri cu valoare culturală.

Amenajamentul silvic permite evaluarea pădurilor care au funcții de recreere prin încadrarea lor la o anumită categorie funcțională din sub-grupa 1.4. S-au identificat astfel $22 \%$ din pădurile incluse la PVRC 6, cuprinzând păduri cu valoare turistică deosebită şi păduri limitrofe traseelor turistice sau zonelor de agreement. De menționat că nu toate pădurile care au atribuită o valoare de recreere conform amenajamentului îndeplinesc pragul critic pentru a fi desemnate PVRC 6.

O altă sursă de date care poate facilita identificarea pădurilor cu valoare culturală, prin raportarea acestora față de localizarea lăcașelor de cult, a cercetărilor arheologice și tumulilor funerari este Serverul Cartografic pentru Patrimoniul Cultural Național (CIMEC 2017). Conform acestei surse au rezultat 73 ha, constituite în majoritatea cazurilor din situri arheologice localizate în păduri și ne-evidențiate de amenajamente (de exemplu situl arheologic Racoș Dealul Vărăriei - figura 11).

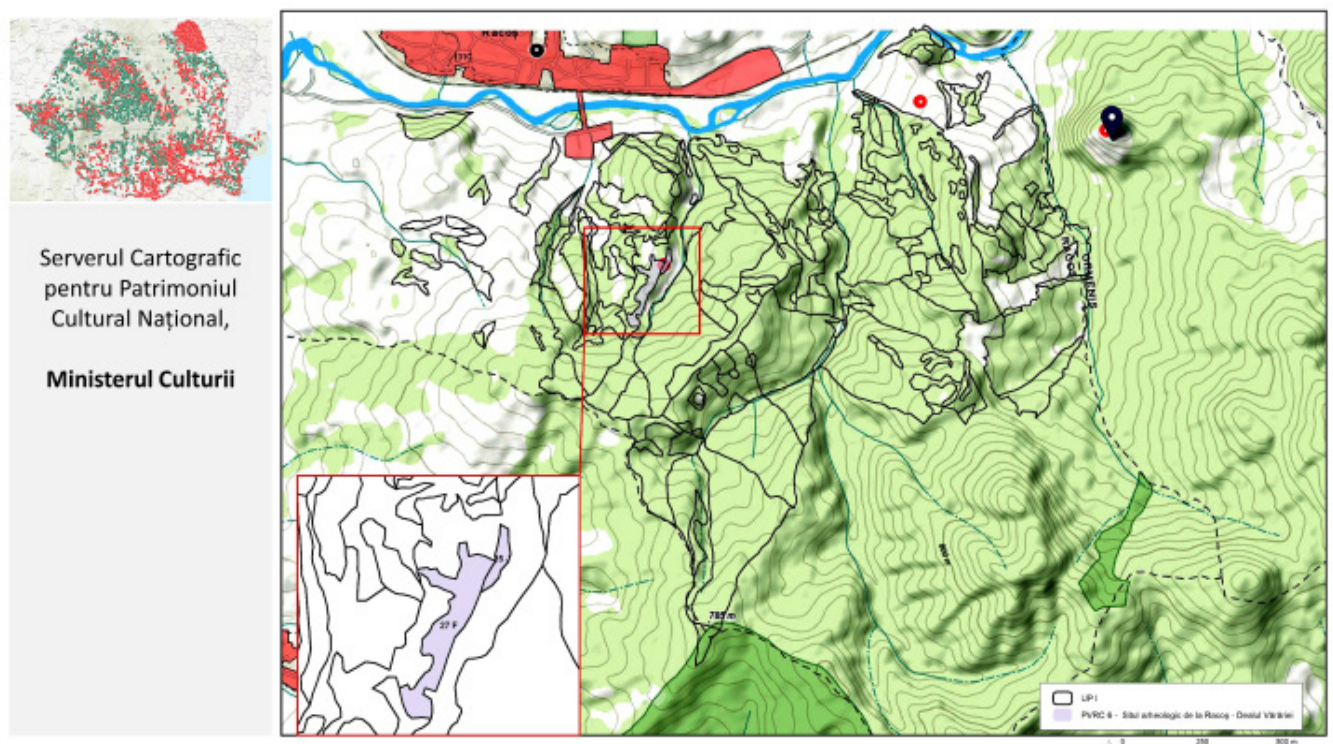

Figura 11 Exemplu de suprapunere a suprafețelor de pădure certificate cu baza cartografică pentru Patrimoniul Cultural Național

Example of a georeferencing certified forest areas using the cartographic basis for the Natural Cultural Heritage 
Pădurile cu rol cultural generează și servicii de mediu cu rol de recreere sau peisagistic. Un important rol social este atribuit și pădurilor limitrofe traseelor turistice reprezentative, păduri care au fost identificate pe o suprafață de 167 ha. De exemplu, un traseu turistic reprezentativ este Via Transilvanica care se suprapune pe o porțiune însemnată cu pădurile OS13 (figura 12). În acest caz, s-a propus o bandă de protectie cu lățimea de $25 \mathrm{~m}$ de-a lungul traseului. Alte trasee turistice au fost identificate folosind hărțile clasice, prin georeferenţierea lor şi suprapunerea cu pădurile certificate (de exemplu traseul Stearpa - Lacul Vulturilor).

În urma consultărilor publice au fost localizate diverse păduri cu valoare culturală, cum ar fi cele limitrofe unor zone în care se organizează serbări câmpenești, zone de agrement, păduri cu valoare peisagistică (ex: poiana cu ghiocei de la Târnava), păduri limitrofe drumurilor europene sau naționale, păduri parc sau păduri limitrofe schiturilor și cimitirelor. Toate acestea reprezintă $79 \%$ din suprafața ocupată de PVRC 6. Drept urmare, pentru identificarea valorilor culturale ale pădurilor principala sursă de informații a fost consultarea factorilor interesați.

\section{Centralizarea surselor de date}

Analiza centralizată a surselor de date arată că pentru $80 \%$ din suprafetele identificate ca PVRC, sursa principală de informații este amenajamentul silvic (figura 13). Acesta acoperă aproape integral cele mai prezente VRC din punct de vedere al mărimii suprafeței identificate, respectiv PVRC 4 și PVRC 1.1.

Conform celor 13 rapoarte analizate, certificarea a contribuit la identificarea suplimentară a unor SE pentru o suprafață de 5756 ha, ceea ce reprezintă $20 \%$ din suprafețele cu PVRC și $5 \%$ din totalul pădurilor incluse în analiză. Principalele valori adiționale țin de:

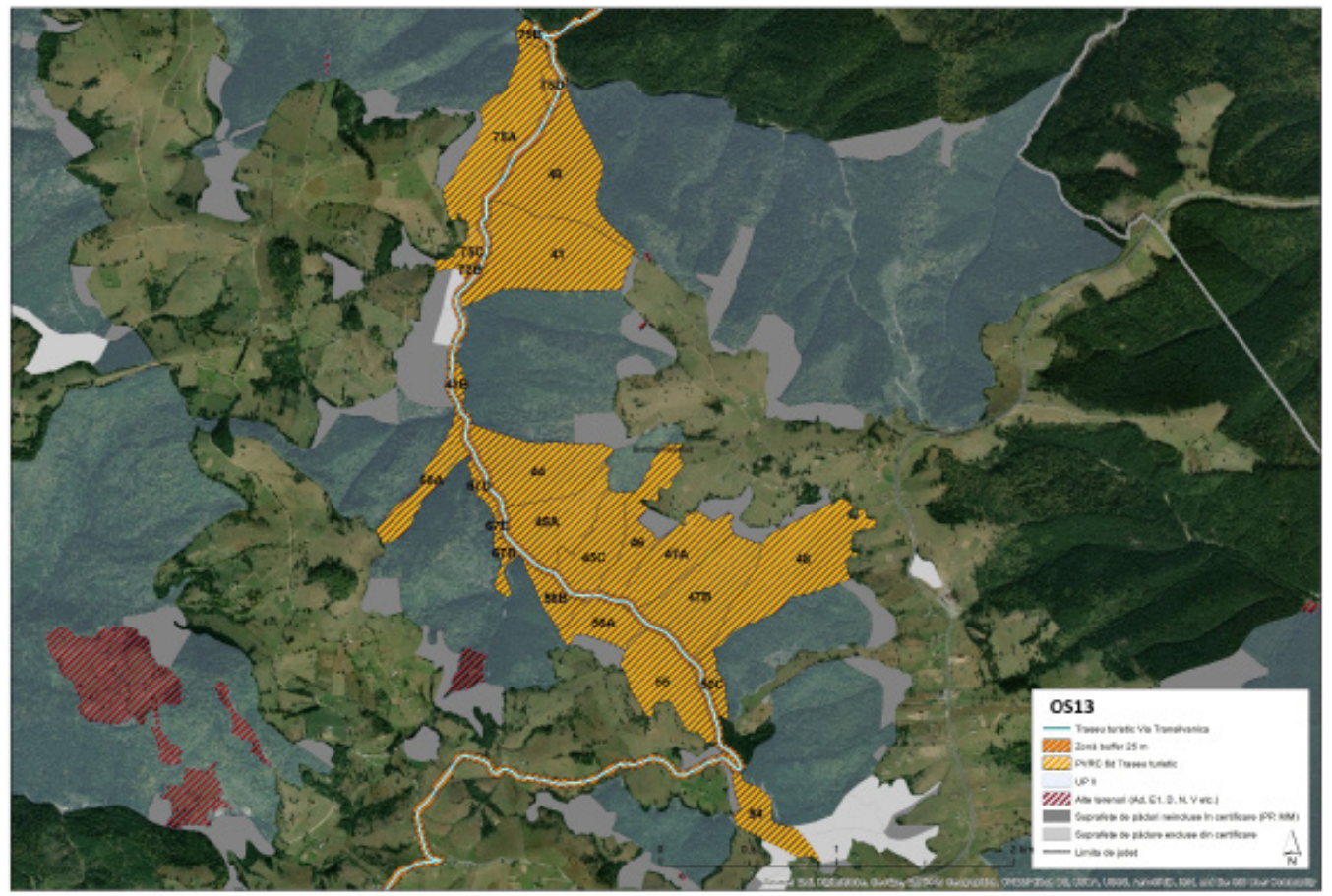

Figura 12 Exemplu de stabilire a zonelor tampon pentru pădurile limitrofe traseelor turistice Example of buffer zones for forest areas intersected by touristic routes 
(i) Armonizarea planurilor de management Natura 2000 cu cerințele amenajistice, în special, prin identificarea localizării geospațiale a speciilor de faună (PVRC 1.3) și floră (PVRC 1.2), prin analiza hărților de distribuție din planurile de management ale ariilor naturale protejate.

(ii) Evaluarea pădurilor cu structuri primare potențiale folosind bazele de date existente, concretizate în validarea a 475 ha de păduri cu structuri primare la categoria PVRC 3.

(iii) Folosirea unor baze de date suport pentru identificarea unor obiective de conservare specifice, cum ar fi, Repertoriul Arheologic Național care semnalează prezența siturilor arheologice în zone cu pădure, respectiv a bazei vectoriale cu captări de apă.

(iv) Implicarea personalului silvic în validarea datelor din amenajamentele silvice și a planurilor de management Natura 2000; excep- tând PVRC 1.1. pentru restul valorilor de conservare, personalul silvic a contribuit activ la identificarea valorilor de conservare adiționale.

(v) Utilizarea de consultări publice care contribuie nu doar la validarea valorilor identificate, ci şi la identificarea unor valori adiţionale, fiind principala sursă de date pentru pădurile cu rol cultural.

\section{Sinteza măsurilor de management propuse pentru PVRC}

Identificarea și cartarea PVRC este doar prima etapă de conformare cu cerințele standardului. Pentru fiecare sub-categorie PVRC este necesară stabilirea măsurilor de management care să ducă la menținerea sau creșterea valorilor de conservare.

Pentru PVRC identificate ca urmare a amenajamentelor silvice, constrângerile care pot

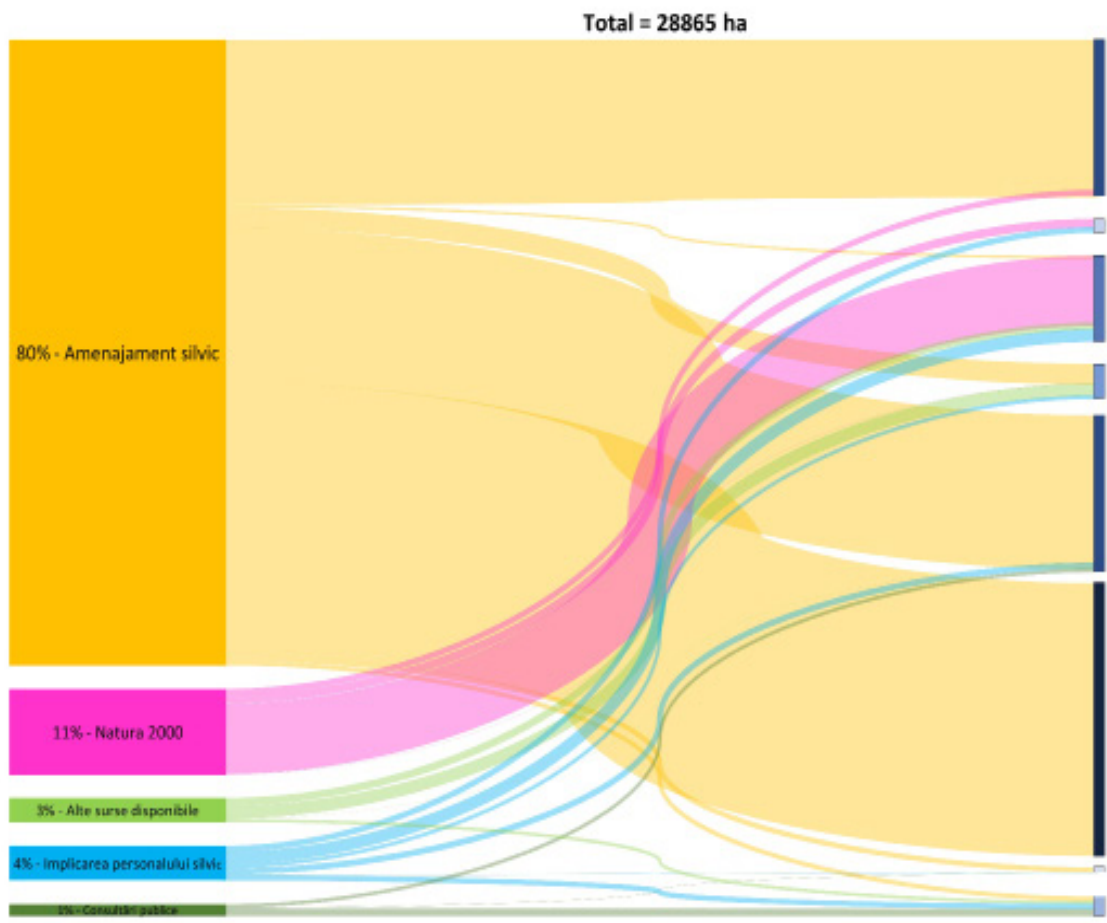

PVRC 1.1. $-22 \%$

PVRC 1.2. $-2 \%$

PVRC 1.3. - $12 \%$

PVRC 3-5\%

PVRC 4.1. - 21\%

PVRC $4.2,-35 \%$

PVRC 4.3. - 1\%

PVRC $6-3 \%$

Figura 13 Sursele de date folosite in procesul de identificare PVRC conform rapoartelor analizate Data sources used in the HCVFs identification according to the analysed reports 
apărea prin stabilirea unor măsuri restrictive sunt mai reduse, ele fiind deja asumate prin zonarea funcțională. Conform datelor analizate, mare parte din suprafețe au deja restricționări impuse prin zonarea funcțională, fiind incluse în SUP E - excluse de la tăieri (pentru PVRC 1.1.) sau în SUP M - lucrări de conservare (pentru PVRC 4.2 și PVRC 4.3). Pentru arboretele identificate în PVRC 4.1, zonarea funcțională impune aplicarea unor tratamente cu perioadă continuă sau lungă de regenerare, specific tipului III de categorii funcționale. În aceste situații, măsurile de management țin de aplicarea corectă a lucrărilor propuse prin amenajament și, în special, de impunerea unor tehnologii de exploatare care să reducă impactul asupra valorilor de conservare identificate.

Pentru PVRC identificate suplimentar amenajamentelor silvice, măsurile de gospodărire recomandate prin rapoartele analizate aduc cerințe adiționale menite să păstreze valoarea de conservare (tabelul 4). În cazul măsurilor generale, acestea fac referire la respectarea regulilor silvice de exploatare, iar cele specifice sunt propuse conform planurile de management Natura 2000 (pentru PVRC 1.2, PVRC 1.3 și PVRC 3). În zonele cu concentrații ridicate de biodiversitate, măsurile de management constau în restricții sezoniere de exploatare (perioada de înflorire, reproducere etc), restricții spaţiale (zone tampon, insule de îmbătrânire etc.) și/sau în păstrarea de arbori morți sau arbori habitat (tabelul 4).

$\mathrm{O}$ altă categorie de măsuri de gospodărire sunt cele asumate voluntar de proprietarii pădurilor certificate. Acestea sunt specifice pădurilor identificate ca având un important rol cultural (PVRC 6), pădurilor în care se regăsesc captări de apă (PVRC 4.1.a) sau pădurilor în care se regăsesc ecosisteme reprezentative (PVRC 3). De exemplu, ținând cont că multe din suprafețele de pădure cu rol cultural sunt limitrofe unor obiective culturale sau de recreere, scopul măsurilor de management este de a reduce impactul social al posibilelor intervenții silviculturale. Măsurile recomandate urmăresc să se creeze zone tampon cu intervenții minimale și să se utilizeze panouri informative pentru turiști.

\section{Sinteza măsurilor de monitorizare propuse pentru VRC}

Monitorizarea PVRC este ultima cerință a standardului pentru a stabilii dacă SE sunt sau nu menținute sau îmbunătățite prin măsurile de management propuse. Conform rapoartelor analizate, se consideră că modificarea valorilor de conservare poate fi consecința unor amenințări de natură biotică sau abiotică, a impactului activităților forestiere sau a evoluției naturale a ecosistemelor forestiere. De aceea, rapoartele propun ca monitorizarea gradului de exercitare a VRC să fie structurată pe trei componente: (i) monitorizarea permanentă - care adresează identificarea amenințărilor general valabile tuturor categoriilor de PVRC, inclusiv acelor zone aflate în zona de protecție strictă; (ii) monitorizarea impactului operațiunilor de exploatare - care adresează identificarea modificărilor VRC în cazul suprafețelor parcurse cu lucrări de exploatare; (iii) monitorizarea specifică care urmărește indicatori specifici de caracterizare a valorilor de conservare.

Monitorizarea permanentă presupune implicarea personalului de teren responsabil cu gospodărirea arboretelor încadrate ca PVRC, personal ce raportează eventualele amenințări (antropice, biotice sau abiotice) sau riscuri care au apărut în aceste arborete.

În situația desfășurării unor activități de exploatare în PVRC, se face apel la prevederile procedurale cerute de certificare, de identificare și reducere a impactului social și de mediu. La punerea în valoare se vor identifica atât zonele care prezintă VRC (de exemplu zone de înflorire, bârloguri de urs, arbori cu cuiburi etc), cât și perioadele în care se poate face exploatarea și măsurile suplimentare necesare păstrării valorilor de conservare. Este necesară materializarea clară pe schița parchetului a zonelor necesar a fi protejate și aducerea la cunoștința agenților de exploatare a cerințelor specifice în raport de VRC-urile prezente. 
Tahel 4 Prezentarea sintetică a măsurilor de management propuse prin rapoartele de identificate analizate Synthesis of the proposed management measures according to analysed HCVFs reports

\begin{tabular}{|c|c|c|}
\hline Categorie & Sub-categorie PVRC & Sinteza măsurilor de management adiționale \\
\hline \multirow[t]{3}{*}{ PVRC 1.} & PVRC 1.1 Arii protejate & $\begin{array}{l}\text { Excluse de la orice intervenție silviculturală conform prevederilor amena- } \\
\text { jistice }\end{array}$ \\
\hline & $\begin{array}{l}\text { PVRC } 1.2 \text { Specii rare, amenințate, } \\
\text { periclitate și endemice }\end{array}$ & $\begin{array}{l}\text { - } \quad \text { Menținerea continuității habitatului speciei; } \\
\text { - Măsurile suplimentare țin de restricționări spațiale pentru amplasarea tăie- } \\
\text { rilor sau a căilor de exploatare, exploatare în afara sezonului de vegetație/ } \\
\text { înflorire a speciilor protejate. }\end{array}$ \\
\hline & $\begin{array}{l}\text { PVRC } 1.3 \text { Utilizarea sezonală } \\
\text { critică }\end{array}$ & 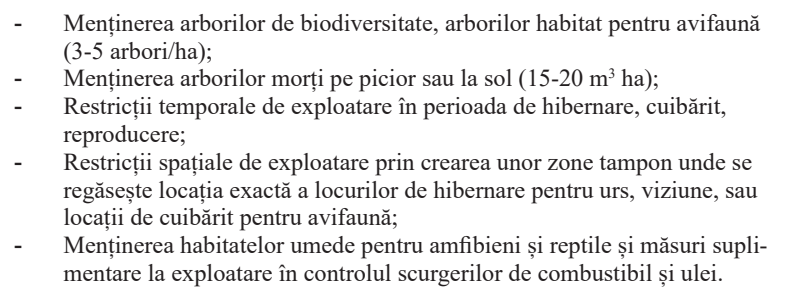 \\
\hline \multirow[t]{4}{*}{ PVRC 3} & $\begin{array}{l}\text { 3a. Păduri, rariști de arbori, tufări- } \\
\text { șuri și complexe de vegetație lem- } \\
\text { noasă cu alte tipuri de vegetație }\end{array}$ & $\begin{array}{l}\text { - } \quad \text { In general, măsurile sunt incluse prin amenajament la categoria lucrărilor } \\
\text { de conservare; } \\
\text { - } \\
\text { Măsurile suplimentare propuse sunt de evitare a intervențiilor, cu excepția } \\
\text { celor de refacere a habitatelor. }\end{array}$ \\
\hline & $\begin{array}{l}\text { 3b. Păduri și tufărișuri rare, relic- } \\
\text { tare, amenințate sau periclitate }\end{array}$ & \\
\hline & $\begin{array}{l}\text { 3c. Ecosisteme forestiere naturale } \\
\text { cu o mare complexitate compoziți- } \\
\text { onală și structurală }\end{array}$ & $\begin{array}{l}\text { - Sunt recomandate măsuri de management activ care să permită menținerea } \\
\text { tipului natural fundamental de pădure cu promovarea speciilor caracteristi- } \\
\text { ce complexității compoziționale }\end{array}$ \\
\hline & $\begin{array}{l}\text { 3d. Ecosisteme forestiere cu } \\
\text { caracter primar }\end{array}$ & $\begin{array}{l}\text { - Măsurile suplimentare propuse sunt de evitare a intervențiilor chiar dacă nu } \\
\text { se îndeplinesc în toate situațiile criteriile de integrare în catalogul național } \\
\text { al pădurilor virgine }\end{array}$ \\
\hline \multirow[t]{3}{*}{ PVRC 4} & $\begin{array}{l}\text { PVRC 4.1. Păduri de importanță } \\
\text { deosebită pentru sursele de apă. }\end{array}$ & $\begin{array}{l}\text { - Măsurile respectă cerințele venite din zonarea funcțională (TIII) cu excep- } \\
\text { ția zonelor tampon la captări de apă, pentru care se propune excluderea de } \\
\text { la tăieri în scop productiv }\end{array}$ \\
\hline & $\begin{array}{l}\text { PVRC 4.2. Păduri critice pentru } \\
\text { prevenirea și combaterea procesu- } \\
\text { lui de eroziune. }\end{array}$ & $\begin{array}{l}\text { - } \quad \text { Se păstrează lucrările silvotehnice propuse conform zonării funcționale } \\
\text { care propun lucrări de conservare; } \\
\text { - } \\
\text { Măsurile specifice țin de modul de realizare a exploatării care trebuie să } \\
\text { reducă impactul asupra solului și să prevină procesul de eroziune. }\end{array}$ \\
\hline & $\begin{array}{l}\text { PVRC 4.3. Păduri cu impact critic } \\
\text { asupra terenurilor agricole şi } \\
\text { calității aerului. }\end{array}$ & $\begin{array}{l}\text { - Se păstrează lucrările silvotehnice propuse conform zonării funcționale } \\
\text { care propun lucrări de conservare. }\end{array}$ \\
\hline PVRC 6 & $\begin{array}{l}\text { Păduri esențiale pentru păstrarea } \\
\text { identității culturale a unei comuni- } \\
\text { tăți sau a unei zone }\end{array}$ & $\begin{array}{l}\text { - } \quad \text { Crearea unor zone tampon în care sunt permise lucrări de îngrijire și de } \\
\text { igienă; } \\
\text { - Crearea unor panouri de promovare dar și de avertizare și atenționare } \\
\text { asupra legalității unor intervenții programate în aceste zone. }\end{array}$ \\
\hline
\end{tabular}

Aceste aspecte se vor monitoriza prin controlul exploatării. La reprimirea parchetului se va stabili gradul de afectare a valorii de conservare conform unor indicatori de monitorizare specifici. Acești indicatori de monitorizare sunt prevăzuți distinct în rapoartele PVRC pentru fiecare categorie identificată. La modul general, indicatorii de monitorizare fac referi- re la identificarea gradului de afectare a stării de conservare în raport de suprafața afectată de factorii perturbatori naturali şi antropici sau de operațiunile de exploatare. 


\section{Discuții}

Analiza a constat în prezentarea structurată a surselor de date folosite pentru identificarea pădurilor care oferă SE considerate cu valoare ridicată de către standardul de certificare FSC. Prezentarea comparativă a procesului voluntar de identificare PVRC, raportată la cerințele amenajistice impuse legislativ, deschide două direcții de discuție.

Pe de o parte, cercetarea confirmă că amenajamentul silvic românesc răspunde în foarte mare măsură cerinţelor de identificare a unor SE altele decât cele de aprovizionare prioritară cu lemn. În special serviciile de reglare (a apelor, solului și calităţii aerului) sunt integrate aproape simetric în clasificarea funcțională românească şi în categoriile de PVRC stabilite la nivel internațional. Aplicarea principiului multi-funcționalității în amenajarea pădurilor a avut drept consecință stabilirea unor măsuri de gospodărie care să asigure menţinerea și regenerarea unor arborete folosind conceptele silviculturii apropiate de natură și a silviculturii conservative (Duduman 2019). Acest lucru se regăsește și în biodiversitatea ridicată, confirmată de faptul că 45\% dintre VRC identificate fac referire la SE de habitat (PVRC 1 și PVRC $3)$.

Din această perspectivă, faptul că un sistem de certificare internațional vine să valideze cerințele normative ale sistemului românesc de amenajare trebuie înțeles ca o oportunitate și nu ca o povară birocratică. Prin acest proces, se oferă posibilitatea administratorilor de păduri să identifice și să promoveze aceste servicii oferite de pădure prin evaluarea lor cantitativă și să le comunice public. Acest lucru poate fi facilitat prin faptul că FSC a lansat în 2018 un serviciu care permite certificarea unui set de cinci SE: conservarea biodiversității, stocarea și retenția carbonului, servicii hidrologice, conservarea solului și servicii recreative (FSC 2018). Aceasta este prima și singura procedură de certificare forestieră internaţională, concepută pentru a certifica, printr-un audit independent terță parte, nu numai sustenabilitatea producției de lemn, dar, în plus, și furnizarea de SE specifice.

Pe de altă parte, analiza arată că abordarea participativă de identificare PVRC conduce la stabilirea unor SE aditionale celor datorate zonării funcționale. Se confirmă că majoritatea SE identificate suplimentar prin certificare sunt în zona serviciilor culturale (Ioraș et al. 2009). Analiza de față arată că sursa lor principală de identificare este legată de rezultatele consultărilor publice. Rolul consultărilor publice este perceput ca una din cele mai importante schimbări pe care o aduce procesul de certificare şi din perspectiva managerilor structurilor silvice de administrare (Hălălișan et al. 2018) aspect confirmat și de contribuția în identificarea SE adiționale.

De asemenea, atât în structurile private cât și în cele de stat cele mai mari schimbări aduse de certificarea forestieră sunt percepute la nivelul măsurilor stabilite pentru protejarea speciilor pe cale de dispariție și a ariilor naturale protejate (Hălălişan et al. 2018). Analiza de față a identificat că măsurile suplimentare de gospodărire sunt impuse în special pentru valorile de conservare a biodiversității (PVRC 1 și PVRC 3). Aceste măsuri suplimentare sunt derivate din prevederile planurilor de management Natura 2000. La nivel european implementarea măsurilor de conservare prevăzute pentru rețeaua Natura 2000 este mai eficientă în situațiile în care stabilirea acestora este rezultatul unui proces participativ (Sotirov 2017). Abordarea participativă a procesului PVRC contribuie astfel și la dezideratul de armonizare eficientă a planurilor Natura 2000 cu planificarea amenajistică.

În majoritatea țărilor europene există însă scheme de compensare a proprietarilor pentru măsurile de management prevăzute în rețeaua Natura 2000 (Sarvašová et al. 2019). În țara noastră, implementarea unui sistem de plăți compensatorii de silvo-mediu se lovește de principiul adiționalității; din cauza cerințelor legislative ridicate, este dificilă identificarea unor măsuri suplimentare față de prevederile amenajamentului sau normelor tehnice (Drăgoi și Cîrnu 2016). Analiza noastră arată că procesul PVRC duce la identificarea unor valori adiționa- 
le care se pot constitui în exemple pentru măsuri financiare de sprijin a furnizării optime a SE. Considerând opțiunile strategice puse la dispoziția autoritătii publice (Popa et al. 2021) este de dorit ca gestionarea acestor servicii adiționale să fie stimulată prin mecanisme financiare de recompensare a voluntariatului şi nu ar trebui să sugereze alte căi de impunere a unor cerințe legislative suplimentare. Întrucât procesul PVRC oferă și indicatori de monitorizare a gradului de menținere a valorilor de conservare, s-ar putea constitui într-un model de fundamentare a unor indicatori de rezultat care să fie folosiţi pentru un sistem de plăți bazat pe performanță.

Implementarea practică a procesului PVRC rezultă însă și în situații non-conforme cu cerințele standardului. În perioada 2008-2017, auditorii au identificat în pădurile certificate din România 45 de situații de neîndeplinire a principiului 9 referitor la PVRC, ceea ce reprezintă $10 \%$ din totalul non-conformităților identificate (Buliga și Nichiforel 2019). Majoritatea acestora sunt legate de identificări sumare PVRC sau de lipsa monitorizărilor pentru PVRC. De asemenea, majoritatea non-conformităţilor identificate de auditori în procesul de certificare vin din zona de exploatare fără respectarea regulilor silvice de exploatare, aspect care poate avea un impact direct asupra menținerii valorilor de conservare. Ca urmare, simpla identificare și cartare a PVRC nu este suficientă fără impunerea unor măsuri clare în procesul de exploatare, activități care să fie implementate și monitorizate.

Rezultatele prezentului studiu nu pot fi generalizate la nivelul întregii suprafețe certificate în România. Rapoartele analizate acoperă aproximativ 5\% din suprafața certificată la nivel național (FSC 2021). Cu toate acestea, zona analizată reprezintă $30 \%$ din suprafaţa celor 27 de ocoalele silvice de regim certificate (Buliga și Nichiforel 2019). De asemenea, disponibilitatea și calitatea informațiilor referitoare la procesul PVRC diferă între entitățile certificate la nivel național. Argumentarea pragului critic de la care se consideră necesară cartarea PVRC este un proces dificil (Vlad et al. 2013) care poate fi 54 afectat de subiectivism. Întrucât procesul PVRC este implementat de proprietarii care aderă la standardul de certificare, SE identificate adițional reprezintă o asumare voluntară a acestora prin raportare la sursele de date existente și a pragurilor recomandate de ghidul de identificare.

\section{Concluzii}

Analiza prezintă modul în care certificarea forestieră, prin procesul de identificare, cartare, management şi monitorizare a PVRC, contribuie la promovarea SE furnizate de păduri. Perspectiva calitativă a studiului ține de structurarea surselor de informație folosite în procesul de identificare PVRC. Faptul că funcțiile atribuite de amenajamentul silvic se regăsesc în $80 \%$ din suprafețele identificate cu PVRC arată că principiul multifuncționalității promovat de sistemul românesc de amenajare asigură furnizarea de SE la un nivel ridicat. $\mathrm{Cu}$ toate acestea, analiza subliniază rolul procesului participativ și a altor surse de date pentru identificarea unor SE adiționale celor din amenajament. Prezentarea surselor relevante (i.e. baze de date georeferentiate disponibile public, consultări publice, implicarea personalului tehnic) oferă exemple metodologice de identificare a unor valorile adiționale, în special pentru SE culturale și de biodiversitate. Măsurile de gestionare propuse preiau în mare parte cerințele de armonizare cu planurile de management Natura 2000, dar sunt legate și de controlul adecvat al regulilor de exploatare forestieră. Acest lucru este sprijinit de stabilirea unor indicatori de monitorizare, ceea ce presupune o abordare directă a relației dintre valoarea de conservare necesar a fi menținută și măsurile de management implementate.

\section{Mulțumiri}

Pentru RES articolul a fost finanțat de proiectul "DECIDE - Dezvoltare prin ed- 
ucație antreprenorială și cercetare inovativă doctorală și postdoctorală, cod proiect POCU/380/13/125031, proiect cofinanțat din Fondul Social European, Programul Operațional Capital Uman 2014-2020". Pentru LN articolul a fost finanțat de proiectul European H2020 Grant 817903 EFFECT.

\section{Bibliografie}

Anonymous, 2018. Ordinul nr. 766/2018 pentru aprobarea Normelor tehnice privind elaborarea amenajamentelor silvice, modificarea prevederilor acestora și schimbarea categoriei de folosință a terenurilor din fondul forestier și a Metodologiei privind aprobarea depășirii posibilității/posibilității anuale în vederea recoltării produselor accidentale I. Ministerul Apelor și Pădurilor. Publicat în Monitorul Oficial, Partea I, nr. 730, 23 August 2018.

Anonymous, 2012. Ordinul nr. 3397/2012 privind stabilirea criteriilor și indicatorilor de identificare a pădurilor virgine şi cvasivirgine în România. Publicat în Monitorul Oficial, Partea I, nr. 668, 24 septembrie 2012.

Anonymous, 2011. Legea nr. 49/2011 pentru aprobarea Ordonanței de urgență a Guvernului nr. 57/2007 privind regimul ariilor naturale protejate, conservarea habitatelor naturale, a florei și faunei sălbatice. Publicat în Monitorul Oficial, Partea I, nr. 262, 13 Aprilie 2011.

Anonymous, 2007. Ordonanța de Urgență nr. 57/2007 privind regimul ariilor natural protejate, conservarea habitatelor naturale, a florei și faunei sălbatice - Guvernul României. Publicat în Monitorul Oficial, Partea I, nr.442, 29 Iunie 2007.

Anonymous, 2000. Legea nr. 5/2000 privind aprobarea Planului de amenajare a teritoriului național - Secțiunea a III-a - zone protejate. Publicat în Monitorul Oficial, Partea I, nr. 152, 12 Aprilie 2000.

Anonymous, 1954. Hotărâre nr. 114/1954 privind zonarea funcțională a pădurilor din republica Populară Română. Publicat în Monitorul Oficial nr. 8 din 30 Ianuarie 1954.

Biriș I.A., Veen P., 2005. Inventory and strategy for sustainable management and protection of virgin forests in Romania PIN-MATRA/2001/018. ICAS and KNNV. Extended English summary.

Buliga B., Nichiforel L., 2019. Voluntary forest certification vs. stringent legal frameworks: Romania as a case study. Journal of cleaner production, 207, pp.329-342. https://doi.org/10.1016/j.jclepro.2018.10.021

CIMEC 2017. Institutul Național al Patrimoniului. Serverul cartografic pentru Patrimoniul Cultural Național. https://map.cimec.ro/Mapserver/?strat=localitati\&cod=2845 (accesat 3 Mai 2021)

Dragoi M., Cîrnu M., 2016. Plata serviciilor ecosistemice: context legal si metode consacrate de evaluare, cu aplicatie la paduri. Bucovina Forestiera, 16(1), p.95. DOI: 10.4316/bf.2016.008
Drăgoi M., 2004. Amenajarea pădurilor. Editura Universităţii din Suceava, 257p.

Duduman G., 2019. Scurt istoric al amenajării pădurilor din România. Bucov.For: 19(2): 139-158. https://doi. org/10.4316/bf.2019.019

European Commission 1992. Council Directive 92/43/ EEC on the conservation of natural habitats and of wild fauna and flora. Published in Official Journal of the European Commission, L. 206.

European Commission 1979. Directive 2009/147/EC on the conservation of wild birds. Published in Official Journal of the European Commission, L. 20.

FSC, 2021. Baza de date internațională FSC. www.info. fsc.org (accesat 3 Mai 2021)

FSC, 2019. National Forest Stewardship Standard of Romania. FSC-STD-ROU-01-2017. https://fsc.org/en/ document-centre/documents/resource/275 (accesat 18 Mai 2021).

FSC, 2018. Ecosystem Services Procedure: Impact Demonstration and Market Tools. FSC-PRO-30-006 V1-0 EN. Bonn. https://fsc.org/en/document-centre/ documents/resource/316 (accesat 18 Mai 2021)

Greenpeace, 2017. Situația pădurilor virgine din România. https://www.greenpeace.org/romania/raport/1235/harta-padurilor-virgine-potentiale-si-studiul-situatia-padurilor-virgine-din-romania/ (accesat 3 Mai 2021)

Halalisan A.F., Abrudan I.V. Popa B., 2018. Forest Management Certification in Romania: Motivations and Perceptions. Forests, 9(7), p.425. https://doi.org/10.3390/ f9070425

Halalisan A.F.; Marinchescu M., 2015. Forest Certification in Romania: The View of the Experts. In Proceedings of the Biennial International Symposium Forest and Sustainable Development; Abrudan, I.V., Borz, A.S., Curtu, A.L., Drosos, V.C., Ignea, G., Indreica, A., Ionescu, O., Ioras, F., Pacurar, V.D., Peltz, D., et al., Eds.; Transilvania University Press: Brasov, Romania; pp. 104-109.

Hălălişan A.F., Marinchescu M. Abrudan, I.V., 2012. The evolution of forest certification: A short review. Bulletin of the Transilvania University of Braşov, Series II, Vol, $5(54)$.

Ioras F., Abrudan I.V., Dautbasic M., Avdibegovic M., Gurean D., Ratnasingam J., 2009. Conservation gains through HCVF assessments in Bosnia-Herzegovina and Romania. Biodiversity and conservation, 18(13), pp.3395-3406. DOI: 10.1007/s10531-009-9649-8

Jennings S., Jarvie J., 2003. A sourcebook for landscape analysis of high conservation value forests. Work funded by the World Wildlife Found organization.

MMAP 2015. Harta zonelor de risc privind recoltarea ilegală a lemnului. http://certificareforestiera.ro/pag/harta_risc_cont.php (accesat 3 Mai 2021)

Millennium Ecosystem Assessment, 2005. Ecosystems and Human Well-being: Synthesis. Island Press, Washington, DC. https://www.millenniumassessment.org/ documents/document.356.aspx.pdf (accesat 12 Aprilie 2021)

Nichiforel L., Duduman G., Scriban R.E., Popa B., Bar- 
noaiea I., Drăgoi M., 2021. Forest ecosystem services in Romania: Orchestrating regulatory and voluntary planning documents. Ecosystem Services, 49, p.101276. https://doi.org/10.1016/j.ecoser.2021.101276

Nichiforel, L., Deuffic, P., Thorsen, B.J., Weiss, G., Hujala, T., Keary, K., Lawrence, A., Avdibegović, M., Dobšinská, Z., Feliciano, D., Górriz-Mifsud, E., Hoogstra-Klein, M., Hrib, M., Jarský, V., Jodłowski, K., Lukmine, D., Malovrh, Š.P., Nedeljković, J., Nonić, D., Ostoić, S.K., Pukall, K., Rondeux, J., Samara, T., Sarvašová, Z., Scriban, R.E., Šilingienè, R., Sinko, M., Stojanovska, M., Stojanovski, V., Stoyanov, T., Teder, M., Vennesland, B., Wilhelmsson, E., Wilkes-Allemann, J., Živojinović, I., Bouriaud, L., 2020. Two decades of forest-related legislation changes in European countries analysed from a property rights perspective. Forest Policy and Economics, 115, p.102146. https:// doi.org/10.1016/j.forpol.2020.102146

Nichiforel L., Hujala T., 2019. Policy instruments and legislation to govern forest ownership. Who owns our forests, pp.86-100.

PEFC, 2021. Baza de date internațională PEFC. https:// www.pefc.org/find-certified (accesat 18 Mai 2021)

Popa B., Nichiforel L., Barnoaiea I., Bouriaud L., Drăgoi M., Enescu C.M., Halalisan A.F., Indreica A., Pacurar V., Baban G., Sfîrlogea S., Scriban R.E., 2021. Rezultate sintetice ale procesului de consultare publică privind opțiunile strategice pentru dezvoltarea politicii forestiere. Raport tehnic. DOI: 10.13140/ RG.2.2.30067.25120

Popa B., Pache R.G., 2016. The concept of ecosystem services-the solution to support the regulation efforts of the forestry sector in Romania. Revista Pădurilor, 131(3/4), pp.41-53.

Sarvašová, Z., Ali, T., Đorđević, I., Lukmine, D., Quiroga, S., Suárez, C., Hrib, M., Rondeux, J., Mantzanas, K.T. and Franz, K., 2019. Natura 2000 payments for private forest owners in Rural Development Programmes 2007-2013-a comparative view. Forest policy and economics, 99, pp.123-135. https://doi.org/10.1016/j.forpol.2017.08.019

Sotirov M., 2017. Natura 2000 and forests: Assessing the state of implementation and effectiveness. What science can tell us, 7.

Stanciu E., Mihul M., Dinicu G., 2005. High conservation value forests toolkit. A practical guide for Romania. WWF-DCP, Bucharest.

Vlad R.G., Bucur C., Turtică M., 2013. Ghid practic pentru identificarea și managementul pădurilor cu valoare ridicată de conservare. Brașov: Green steps, 106 p. http://awsassets.panda.org/downloads/Ghid-pvrc-web. pdf (accesat 17 Aprilie 2021)

TEEB 2010. The economics of ecosystems and biodiversity: mainstreaming the economics of nature: A synthesis of the approach, conclusions and recommendations of TEEB., 36. Malta: UNEP 